\title{
Binding of Oxovanadium(IV) Complexes to Blood Serum Albumins
}

Enoch Cobbina, ${ }^{a, b}$ Sameena Mehtab, ${ }^{a}$ Isabel Correia, ${ }^{a}$ Gisela Gonçalves, ${ }^{a}$ Isabel Tomaz, ${ }^{c}$ Isabel Cavaco, ${ }^{b}$ Tamás Jakusch, ${ }^{d}$ Eva Enyedi, ${ }^{e}$ Tamás Kiss, ${ }^{d, e}$ and João Costa Pessoa*a

a Centro de Química Estrutural, Instituto Superior Técnico, Universidade Técnica de Lisboa, Av. Rovisco Pais 1, 1049-001

Lisboa, Portugal. Tel: +351 218419268, joao.pessoa@ist.utl.pt.

b Departamento de Química, Bioquímica e Farmácia, Universidade do Algarve, Campus de Gambelas, 8005-139 Faro, Portugal

c Centro de Ciências Moleculares e Materiais, Faculdade de Ciências da Universidade de Lisboa, Ed. C8, Campo Grande, Campo Grande, 1749-016 Lisboa. Portugal

d Department of Inorganic and Analytical Chemistry, University of Szeged, Dóm tér 7, Szeged H-6720, Hungary

e Institute of Structural Chemistry, Chemical Research Center, Hungarian Academy of Sciences, Pusztaszeri út 59-67, H-1025 Budapest, Hungary

Received December 6, 2012; Acepted June 5, 2013.

\begin{abstract}
In this work the binding of $\mathrm{V}^{\mathrm{IV}} \mathrm{O}^{2+}$ and $\mathrm{V}^{\mathrm{IV}} \mathrm{O}$-complexes to serum albumins \{human serum albumin (HSA), bovine serum albumin (BSA) and porcine serum albumin (PSA) $\}$ are studied using circular dichroism (CD), electron paramagnetic resonance (EPR) and visible absorption spectroscopy. The results confirm previous findings that $\mathrm{V}^{\mathrm{IV}} \mathrm{O}^{2+}$ occupies at least two types of binding sites on albumin: 'the strong vanadium binding site' (designated by VBS1) and 'the weak vanadium binding sites' (designated by VBS2). VBS1 binds 1 mol equivalent of $\mathrm{V}^{\mathrm{IV}} \mathrm{O}^{2+}$. On the other hand $\mathrm{VBS} 2$ correspond to binding of several mol equivalents of $\mathrm{V}^{\mathrm{IV}} \mathrm{O}$, and studies done with PSA in the presence of excess $\mathrm{Zn}^{\mathrm{II}}$ ions indicate that VSB2 corresponds to two distinct types of sites. The hyperfine coupling constant $A_{\mathrm{z}}$ for $\mathrm{V}^{\mathrm{IV}} \mathrm{O}^{2+}$ binding at VBS2 on HSA and BSA are all very similar $\left(\sim 168 \times 10^{-4}\right.$ $\left.\mathrm{cm}^{-1}\right)$ but differ slightly on PSA $\left(\sim 166 \times 10^{-4} \mathrm{~cm}^{-1}\right)$ due to differences in the binding sets. When $\left(\mathrm{V}^{\mathrm{IV}} \mathrm{O}\right)$-HSA systems are titrated with maltol ternary species of (maltol $)_{\mathrm{m}}\left(\mathrm{V}^{\mathrm{IV}} \mathrm{O}\right)_{\mathrm{m}} \mathrm{HSA}$ and (maltol $)_{2 \mathrm{~m}}\left(\mathrm{~V}^{\mathrm{IV}} \mathrm{O}\right)_{\mathrm{m}} \mathrm{HSA}$ stoichiometry form which are clearly distinguishable from the binary $\left(\mathrm{V}^{\mathrm{IV}} \mathrm{O}\right)-\mathrm{HSA}$ system by the type and intensity of the CD spectra recorded. Changes are also observable in the intensity of the X-band EPR spectra, but not much in the hyperfine coupling constants $A_{\mathrm{Z}}$, which are all in the range $166-167 \times 10^{-4} \mathrm{~cm}^{-1}$. The results further demonstrate that the presence of maltol may enhance the binding of $\mathrm{V}^{\mathrm{IV}} \mathrm{O}$ to albumin.
\end{abstract}

Key words: Oxovanadium(IV), Circular Dichroism, Electron Paramagnetic Resonance, maltol, human serum albumin, bovine serum albumin, porcine serum albumin.

\section{Introduction}

The interactions of $\mathrm{V}^{\mathrm{IV}} \mathrm{O}^{2+}$ with serum proteins are important to its pharmacokinetic properties. The studies carried out to investigate the significance of vanadium as well its compounds in biological systems have led to the discovery of its potential as a therapeutic agent. Many publications illustrate its insulin-mimetic [1, 2], anti-cancer [3-5], anti-parasitic [6, 7] antimicrobial $[8,9]$ and antispermicidal [10] actions. $\mathrm{V}^{\mathrm{IV}} \mathrm{O}$ and its complexes show high potential for the treatment of type- 2 diabetes, and prospective uses for other diseases [11-20].

It is believed that ligands such as maltol, dhp (Hdhp $=1,2-$ dimethyl-3-hydroxy-4(1H)-pyridinone, Scheme 1), picolinato, dipicolinato and acetylacetonato, may enhance the insulin mi-
Resumen. En este trabajo el enlace de $\mathrm{V}^{\mathrm{IV}} \mathrm{O}^{2+}$ y los $\mathrm{V}^{\mathrm{IV}} \mathrm{O}$-complejos a albúminas séricas \{albúmina sérica humana (HSA), albúmina sérica bovina (BSA) y la albúmina sérica porcina (PSA)\} son estudiadas usando el dicroísmo circular (CD), la resonancia paramagnética electrónica (EPR) y la espectroscopia de absorción visible. Los resultados confirman hallazgos previos que el $\mathrm{V}^{\mathrm{IV}} \mathrm{O}^{2+}$ ocupa al menos dos tipos de unión a la albúmina: 'un fuerte lugar de unión del vanadio' (designado por VBS1) y 'unos lugares débil de unión al vanadio' (designados por VBS2). VBS1 se une a 1 equivalente molar de $\mathrm{V}^{\mathrm{IV}} \mathrm{O}^{2+}$. Por otra parte VBS2 corresponde a la unión de varios equivalentes molares de $\mathrm{V}^{\mathrm{IV}} \mathrm{O}$, y estudios hechos con PSA en presencia de exceso de iones de $\mathrm{Zn}^{\mathrm{II}}$ corresponden a dos distintos tipos de lugares. La constante de acoplamiento hiperfino $A_{\mathrm{z}}$ para $\mathrm{V}^{\mathrm{IV}} \mathrm{O}^{2+}$ unido a VBS2 en HSA y BSA son todas muy similares $\left(\sim 168 \times 10^{-4} \mathrm{~cm}^{-1}\right)$ pero difieren ligeramente en el PSA $\left(\sim 166 \times 10^{-4} \mathrm{~cm}^{-1}\right)$ debido a las diferencias en los lugares de enlace. Cuando los sistemas $\left(\mathrm{V}^{\mathrm{IV}} \mathrm{O}\right)$-HSA se valoraron con especies ternarias de maltol (maltol $)_{\mathrm{m}}\left(\mathrm{V}^{\mathrm{IV}} \mathrm{O}\right)_{\mathrm{m}} \mathrm{HSA}$ y (maltol $)_{2 \mathrm{~m}}\left(\mathrm{~V}^{\mathrm{IV}} \mathrm{O}\right)_{\mathrm{m}} \mathrm{HSA}$ de forma estequiométrica las cuales son claramente distinguibles del sistema binario $\left(\mathrm{V}^{\mathrm{IV}} \mathrm{O}\right)$-HSA por el tipo y la intensidad del espectro de $C D$ registrado. También se observa cambios en la intensidad de la banda-X del espectro de EPR, pero no tanto en la constante de acoplamiento hiperfino $A_{\mathrm{z}}$, que están todos en el rango de $166-167 \times 10^{-4}$ $\mathrm{cm}^{-1}$. Los resultados demuestran además que la presencia del maltol puede mejorar el enlace de $\mathrm{V}^{\mathrm{IV}} \mathrm{O}$ a la albúmina.

Palabras clave: Oxovanadium(IV), Circular Dichroism, Electron Paramagnetic Resonance, maltol, human serum albumin, bovine serum albumin, porcine serum albumin.

metic properties of $\mathrm{V}^{\mathrm{IV}} \mathrm{O}^{2+}[1,12-20]$. However, when $\mathrm{V}^{\mathrm{IV}} \mathrm{O}^{2+}$ is administered as a complex, designated here as $\mathrm{V}^{\mathrm{IV}} \mathrm{O}(\text { carrier })_{\mathrm{n}}$, it may undergo transformations in the gastrointestinal tract, through the circulation and finally in the tissues and cells [1, 19-26]. It was reported that the complex undergoes rapid dissociation at the site of absorption, both $\mathrm{V}^{\mathrm{IV}} \mathrm{O}^{2+}$ and the carrier ligand following different pharmacokinetic pathways [1, 18-20]. Notwithstanding, many other studies have shown differences in activity between $\mathrm{V}^{\mathrm{IV}} \mathrm{O}^{2+}$ administered as a salt $\left(\mathrm{V}^{\mathrm{IV}} \mathrm{OSO}_{4}\right)$ and as $\mathrm{V}^{\mathrm{IV}} \mathrm{O}(\text { carrier })_{\mathrm{n}}$ complexes (examples in Figure 1) [17, $18,24,26]$.

Albumin is the most abundant large globular protein in the blood serum of mammals and is important for several physiological functions $[27,28]$. Albumin has multiple specific and 

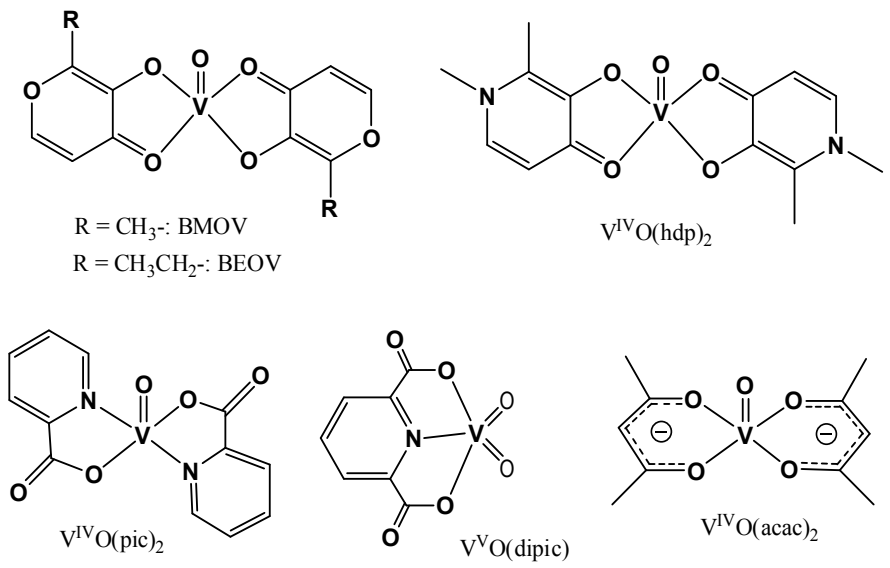

Scheme 1. Several of the reported insulin mimetic compounds \{most are $\mathrm{V}^{\mathrm{IV}} \mathrm{O}$ (carrier) $)_{2}$ complexes $\}$; Hpic = picolinic acid (pic), Hdhp = 1,2-dimethyl-3-hydroxy-4(1H)-pyridinone, and acac = acetylacetonato, $\mathrm{H}_{2}$ dipic $=$ dipicolinic. $\mathrm{V}^{\mathrm{IV}} \mathrm{O}$ complexes with maltol $(\mathrm{BMOV})$ and ethyl-maltol (BEOV) are also represented.

non-specific binding sites where a large number of endogenous and exogenous substances bind. The composition of HSA, BSA and PSA are similar; however, there are some variations in the number and sequence of their amino acids [27]. Namely, HSA contains only one [29] tryptophan while both BSA and PSA contain two [27] each; due to this difference the molar absorptivity of the band at $\sim 280 \mathrm{~nm}$ for HSA is about $20 \%$ lower than that of BSA.

Concerning metal ion binding, despite the lack of detailed structural information about the binding sites on human albumin, four sites have been described [30]: (1) the Amine Terminal $\mathrm{Cu}$ (II) and $\mathrm{Ni}$ (II) site, often designated by ATCUN is at the N-terminus, the primary binding site for $\mathrm{Cu}^{\mathrm{II}}$ and $\mathrm{Ni}$; ; [27, 30]; (2) the multi-metal binding site (MBS) which primarily binds $\mathrm{Zn}$ II and a few other +2 metal ions [30]; (3) site B which is the primary binding site for $\mathrm{Cd}^{\mathrm{II}}$ but can also bind $\mathrm{Zn}^{\mathrm{II}}$ [30-32], and (4) the reduced thiol of Cys-34, which binds gold and platinum compounds $[30,33]$.

There are 14 conserved His residues in human, bovine and porcine albumins [31], but only three of them are located close enough to each other in space to provide a strong binding site for metal ions. An important difference between the three albumins is the ATCUN motif: (i) HSA has Asp-1, Ala2, and His-3 at the N-terminus, (ii) BSA has Asp-1, Thr-2 and His-3, while (iii) PSA has His-3 substituted by Tyr-3. $[27,34]$ Other groups such as carboxylates and amides may also play roles in metal ion binding to albumin. It is considered that for BSA the primary binding site for $\mathrm{Cu}^{\mathrm{II}}$ is also the 3 residues of its N-terminal site, while for PSA, although $\mathrm{Cu}$-binding would be possible, data indicate it is elsewhere in the protein [30]. The positions of the CD bands and EPR parameters for $\mathrm{Cu}^{\mathrm{II}}$ bound at the MBS suggest coordination and tetragonal binding geometry, and globally the the similarity of the several spectroscopic parameters between albumins suggest that the MBS has been mostly conserved during evolution.
Several studies have reported the binding of $\mathrm{V}^{\mathrm{IV}} \mathrm{O}^{2+}$ to albumin [25, 34-39]. Chasteen and Francavilla identified two classes of binding sites on albumin: 'strong' and 'weak' [39]. The ATCUN motif was reported to be the VSB1 site and to bind 1 mol equivalent of $\mathrm{V}^{\mathrm{IV}} \mathrm{O}^{2+}[27,39]$. The weak sites of $\mathrm{V}^{\mathrm{IV}} \mathrm{O}^{2+}$ (VBS2) were considered to consist of a number of non-specific interactions that may involve carboxylate or imidazole side chains of amino acid residues [38, 39], and Chasteen reported at least five non-specific interactions [39].

Garribba et al. detected a dinuclear $\left(\mathrm{V}^{\mathrm{IV}} \mathrm{O}\right)_{2} \mathrm{HSA}$ species by EPR at $-150{ }^{\circ} \mathrm{C}$ [36]. The spin state of this species is 1 , it is observed up to a $\mathrm{V}^{\mathrm{IV}} \mathrm{O}$ :HSA ratio of $1: 1$ and the intensity of the spectrum is very low. At $\mathrm{V}^{\mathrm{IV}} \mathrm{O}: \mathrm{HSA}>1$ another type of EPR spectrum (spin 1/2) becomes predominant and no other distinct type of spectrum is observed up to a $\mathrm{V}^{\mathrm{IV}} \mathrm{O}: \mathrm{HSA}$ ratio of $8: 1$. Notwithstanding, the $\mathrm{V}^{\mathrm{IV}} \mathrm{O}$ binding to amino acid side chains of the ATCUN motif, if occurring, differs from $\mathrm{Cu}^{\mathrm{II}}$ binding to the same site. In studies with small oligopeptides, in the absence of a primary anchor donor group $\mathrm{V}^{\mathrm{IV}} \mathrm{O}$ ions (similarly to $\mathrm{Cu}^{\mathrm{II}}$ ) are not able to induce the deprotonation of the amide groups [36, 40-42]; in fact the N-terminal amino group is a suitable anchor for $\mathrm{Cu}^{\mathrm{II}}$, but not for $\mathrm{V}^{\mathrm{IV}} \mathrm{O}$ [40-45].

Sakurai \& co-workers [34] compared the CD spectra of solutions containing BSA and $\mathrm{V}^{\mathrm{IV}} \mathrm{O}^{2+}$ and of solutions containing iodoacetamide-BSA and $\mathrm{V}^{\mathrm{IV}} \mathrm{O}^{2+}$. The non-detection of the positive $C D$ band at $590 \mathrm{~nm}$ was considered to demonstrate the binding of $\mathrm{V}^{\mathrm{IV}} \mathrm{O}$ to the thiolate of $\mathrm{Cys} 34$; the second binding site of $\mathrm{Cu}^{\mathrm{II}}$ was also considered to be this thiolate donor [34]. However, this binding for $\mathrm{Cu}^{\mathrm{II}}$ contradicts the results of Bal [31] and those of other groups $[37,38]$. So, up to date, the actual groups that form the vanadium binding sites are not well known.

$\mathrm{CD}$ and EPR data showed that $\mathrm{V}^{\mathrm{IV}} \mathrm{O}^{2+}$ occupies two types of binding sites in albumin, which compete not only with each other, but also with hydrolysis of the metal ion [37]. In one of the sites the resulting $\mathrm{V}^{\mathrm{IV}} \mathrm{O}-\mathrm{HSA}$ complex has a weak CD signal in the visible range and its X-band EPR spectrum may be easily measured. This was assigned to amino acid side chains of the ATCUN site. The other binding site showed stronger signals in the $\mathrm{CD}$ in the visible range and was assigned to the multi metal binding site (MBS) of HSA. However, the possibility of binding of at least $6 \mathrm{~mol}$ equivalents of $\mathrm{V}^{\mathrm{IV}} \mathrm{O}$ to HSA suggests that the situation is more complex. Therefore, one of the objectives of this work is to clarify the nature of the $\mathrm{V}^{\mathrm{IV}} \mathrm{O}^{2+}$ binding sites at HSA. For this purpose we also include here studies of the $\mathrm{V}^{\mathrm{IV}} \mathrm{O}+\mathrm{BSA}$ and $\mathrm{V}^{\mathrm{IV}} \mathrm{O}+$ PSA systems.

Vanadium(IV) and its complexes of maltol have attracted much attention due to their anti-diabetic effects [1]. $\mathrm{V}^{\mathrm{IV}} \mathrm{O}^{2+}$ is able to interact with maltol to form ternary species when bound to albumin, supporting the possibility of transport of $\mathrm{V}^{\mathrm{IV}} \mathrm{O}^{2+}$ in blood plasma in the form of $\mathrm{V}^{\mathrm{IV}} \mathrm{O}-\mathrm{HSA}$-maltol species. The ternary species formed may be of two types: $\left(\mathrm{V}^{\mathrm{IV}} \mathrm{OL}_{2}\right)_{\mathrm{n}}(\mathrm{HSA})$ or $\left(\mathrm{V}^{\mathrm{IV}} \mathrm{OL}\right)_{\mathrm{n}}(\mathrm{HSA})$. The system has been studied by several groups $[12-15,37]$ some indicating the formation of $\left(\mathrm{V}^{\mathrm{IV}} \mathrm{OL}\right)_{\mathrm{n}}(\mathrm{HSA})$, others the formation of $\left(\mathrm{V}^{\mathrm{IV}} \mathrm{OL}_{2}\right)_{\mathrm{n}}(\mathrm{HSA})$. In this work we also further study this system to clarify the type of $\mathrm{V}^{\mathrm{IV}} \mathrm{O}$-maltolHSA species formed. 


\section{Experimental}

\section{Materials and preparation of solutions}

The chemical reagents and albumins were used as received from the supplier without further purification.

Millipore ${ }^{\circledR}$ water was used for the preparation of the solutions and a HEPES buffer was used in most experiments (except RT EPR). The composition of the buffer designated as HEPES-S used was: $50 \mathrm{mM}$ HEPES (Sigma-Aldrich), $25 \mathrm{mM}$ carbonate added as $\mathrm{NaHCO}_{3}$ (Sigma-Aldrich), $1 \mathrm{mM}$ phosphate added as $\mathrm{NaH}_{2} \mathrm{PO}_{4} \cdot \mathrm{H}_{2} \mathrm{O}$ (Merck), and $0.20 \mathrm{mM} \mathrm{KCl}$ (Merck); the buffer was adjusted to $\mathrm{pH} 7.4$ using conc. $\mathrm{KOH}$ and conc. $\mathrm{HCl}$.

Fatted HSA (A1653, fHSA) and defatted HSA (A3782, dHSA), defatted BSA (A-7511, dBSA), fatted BSA (A3675, fBSA) and fatted PSA (A1830, fPSA) were purchased from Sigma-Aldrich. Maltol, and $\mathrm{V}^{\mathrm{IV}} \mathrm{OSO}_{4}$ were also purchased form Sigma-Aldrich.

The molecular weight as well as the molar extinction coefficients used for the determination of albumin concentrations were: (1) $66.5 \mathrm{kDa} ; \varepsilon(278 \mathrm{~nm})=36850 \mathrm{M}^{-1} \mathrm{~cm}^{-1}$ for fatted HSA and defatted HSA [46-49] (2) defatted BSA (66,430 Da; $\left.\varepsilon_{280}=44,300 \mathrm{M}^{-1} \mathrm{~cm}^{-1}\right)$; and (3) fatted PSA (67,900 Da; $\varepsilon_{280}$ $\left.=45,600 \mathrm{M}^{-1} \mathrm{~cm}^{-1}\right)[22,36,48]$. These values were obtained from the indicated references and product information documents from Sigma.

Albumin solutions: The albumin solutions were prepared by dissolving the protein in HEPES-S buffer. The solutions were allowed to stand for at least 60 minutes to allow equilibration. During this period the solutions were gently swirled; strong agitation was never done. The concentrations were then determined by UV spectrophotometry. Argon was gently bubbled through all solutions prior to use to displace any oxygen that may be present, and these were kept and manipulated under the argon atmosphere inside a glove bag.

Metal ion solutions: with the exception of the $\mathrm{V}^{\mathrm{IV}} \mathrm{O}$ stock solution $\left\{\mathrm{V}^{\mathrm{IV}} \mathrm{O}\left(\mathrm{ClO}_{4}\right)_{2}\right\}$, prepared as described previously [50]. Degassed and stored under nitrogen atmosphere in closed glassware, all other metal ion solutions were freshly prepared by dissolving them in Millipore ${ }^{\circledR}$ water. The concentration of the stock $\mathrm{V}^{\mathrm{IV}} \mathrm{O}\left(\mathrm{ClO}_{4}\right)_{2}$ solution was $9.90 \mathrm{mM}$.

Titrations: in all titrations the albumin solution was titrated by adding $\mu \mathrm{L}$ aliquots of the other compounds to obtain the desired molar ratios. The UV-Vis and CD spectra of the solutions were measured, and samples were taken and frozen at 77 $\mathrm{K}$ for EPR measurements.

\section{Spectroscopic measurements}

The visible absorption spectra of the solutions were recorded on a Perkin Elmer Lambda $35 \mathrm{UV} / \mathrm{V}$ is spectrophotometer in the range 400 - $1000 \mathrm{~nm}$ with quartz Suprasil ${ }^{\circledR}$ cuvettes. The circular dichroism (CD) spectra of the solutions were recorded on a JASCO J-720 spectropolarimeter (JASCO, Hiroshima, Japan) using a red-sensitive photomultiplier (EXEL-308) in the visible region of the electromagnetic spectrum (400-1000 nm). Most of the $\mathrm{CD}$ recordings were done at $\sim 25^{\circ} \mathrm{C}$ with a $50 \mathrm{~mm}$ quartz cell. One to three accumulations were made for each measurement. The CD spectra were obtained in mdeg units which were converted to $\Delta \varepsilon$ values (in $\mathrm{M}^{-1} \mathrm{~cm}^{-1}$ units) based on the concentration of the albumin present. $\Delta \varepsilon$ values may be positive or negative [51] and when it is stated that the CD signals increase or decrease, this corresponds to the $|\Delta \varepsilon|$ values.

The X-band EPR $(\sim 9.46 \mathrm{GHz})$ spectra were measured either at room temperature (RT) or at liquid nitrogen (LN) temperature $(77 \mathrm{~K})$. The spectra at $77 \mathrm{~K}$ were recorded on a Bruker ESP $300 \mathrm{E}$ spectrometer. To improve the signal to noise ratio 10 scans were accumulated for each sample. The spectra acquisition parameters were constant for each batch of experiments. All measurements were done using $3 \mathrm{~mm}$ quartz tubes (Wilmad 707-SQ-250 M). The EPR samples contained 5\% DMSO.

To facilitate the description of the composition of each solution we will often describe a solution that contains e.g. HSA and $\mathrm{Cu}^{\mathrm{II}}$ in a 1:2 molar ratio by $\mathrm{Cu}_{2} \mathrm{HSA}$, or a solution with BSA and $\mathrm{V}^{\mathrm{IV}} \mathrm{O}$ in a $1: 4$ molar ratio by $\left(\mathrm{V}^{\mathrm{IV}} \mathrm{O}\right)_{4} \mathrm{BSA}$. In some occasions a similar designation will be used to specify a particular metal complex species. The designation $\mathrm{V}^{\mathrm{IV}} \mathrm{O}^{2+}$ is used when referring to the $\mathrm{V}^{\mathrm{IV}} \mathrm{O}\left(\mathrm{H}_{2} \mathrm{O}\right)_{5}{ }^{2+}$ or $\mathrm{V}^{\mathrm{IV}} \mathrm{O}^{2+}$ as cations; the designation $\mathrm{V}^{\mathrm{IV}} \mathrm{O}$ is used when referring to this unit in a complex species, e.g. $\left(\mathrm{V}^{\mathrm{IV}} \mathrm{O}\right)_{4} \mathrm{BSA}$.

\section{Results and discussions}

\section{Binding sites of $\mathrm{V}^{\mathrm{IV}} \mathrm{O}^{2+}$ on albumin}

The visible CD spectra pattern of $\left(\mathrm{V}^{\mathrm{IV}} \mathrm{O}\right)_{\mathrm{m}}$-HSA complexes is shown in Figures 1 and 2 . The $\left(\mathrm{V}^{\mathrm{IV}} \mathrm{O}\right)_{\mathrm{m}}$-HSA complexes produce both negative and positive bands in the visible range of the CD spectrum. The positive bands are observed approximately between 520 and $730 \mathrm{~nm}$ with band 'maxima' $\left(\lambda_{\max }\right)$ at 588 $\mathrm{nm}$, while the negative band appears between $730 \mathrm{~nm}$ and 1000 $\mathrm{nm}$ with $\lambda_{\max }$ at $\sim 832 \mathrm{~nm}$. Another negative band is observed at $\lambda<520 \mathrm{~nm}$.

Below 1 mol equivalent of $\mathrm{V}^{\mathrm{IV}} \mathrm{O}^{2+}$ the $\mathrm{CD}$ signals are very low (Figure 1). This applies to both defatted and fatted HSA$\mathrm{V}^{\mathrm{IV}} \mathrm{O}$ complexes, but the intensity is significantly higher for the defatted $\left(\mathrm{V}^{\mathrm{IV}} \mathrm{O}\right)_{\mathrm{m}}$-HSA solutions. The intensity of the $\mathrm{CD}$ spectra globally increases upon addition of $\mathrm{V}^{\mathrm{IV}} \mathrm{O}^{2+}$ up to $\mathrm{V}^{\mathrm{IV}} \mathrm{O}$ : HSA molar ratios of 9 (Figure 2).

The d-d electronic transitions of $\left(\mathrm{V}^{\mathrm{IV}} \mathrm{O}\right)_{\mathrm{m}}$-HSA species is manifested in the $C D$ spectrum in the visible range when it is coordinated by donor atoms where chirality is effectively transferred from the chiral centres of the protein to the $\mathrm{V}^{\mathrm{IV}} \mathrm{O}$ centre [51-57]. Binding to donor groups of amino acid residues of albumin may thus result in the manifestation of d-d transitions in the visible $\mathrm{CD}$ spectrum [22, 31, 37]. Considering the many possible binding sites of $\mathrm{V}^{\mathrm{IV}} \mathrm{O}^{2+}$ on albumin, each mol equivalent of $\mathrm{V}^{\mathrm{IV}} \mathrm{O}^{2+}$ may produce a visible $\mathrm{CD}$ spectrum that may show some variations depending on the amino acid residues coordinating it and the environment of the site. What 


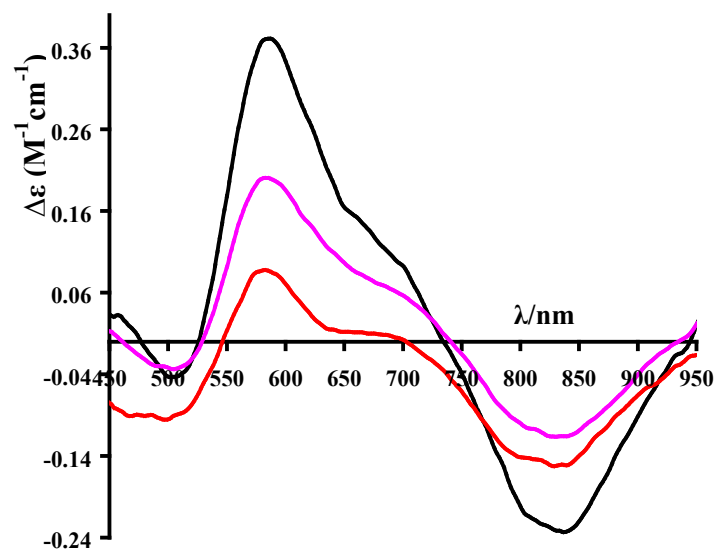

Fig. 1. Comparison of the spectral pattern of defatted $(1 \mathrm{mM})$ and fatted HSA $(0.7 \mathrm{mM})$ complexes of $\mathrm{V}^{\mathrm{IV}} \mathrm{O}^{2+}$. $\mathrm{V}^{\mathrm{IV}} \mathrm{O}$ complexes of defatted HSA are significantly more intense. The following molar ratios were used: dHSA: $\mathrm{V}^{\mathrm{IV}} \mathrm{O}^{2+}$ of 1:5 (black), dHSA: $\mathrm{V}^{\mathrm{IV}} \mathrm{O}^{2+}$ of 1:3 (pink), fHSA: $\mathrm{V}^{\mathrm{IV}} \mathrm{O}^{2+}$ of 1:4.4 (red), Measurements were carried out in HEPES-S buffer $(\mathrm{pH}=7.4)$ with an optical path of $5 \mathrm{~cm}$.

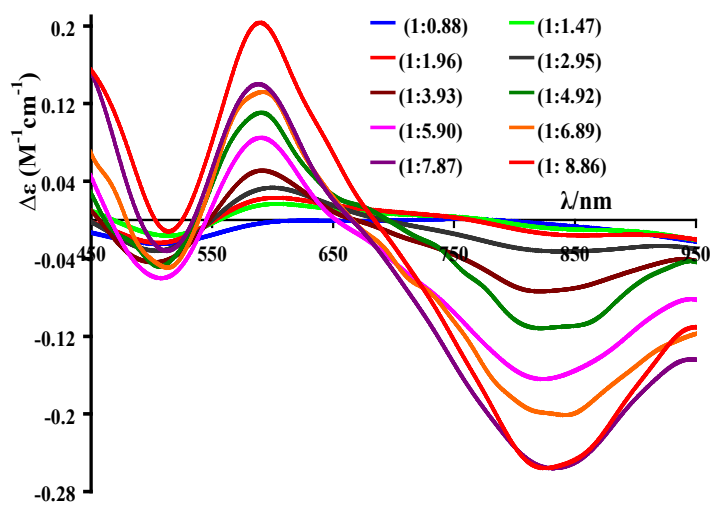

Fig. 2. Changes in intensities of the positive $(\sim 588 \mathrm{~nm})$ and negative $(\sim 832 \mathrm{~nm})$ bands of the fHSA-V $\mathrm{V}^{\mathrm{IV}} \mathrm{O}$ complexes. More than ca. $2 \mathrm{~mol}$ equivalents of $\mathrm{V}^{\mathrm{IV}} \mathrm{O}^{2+}$ are required to produce spectra with $\mathrm{CD}$ larger than $0.05 \mathrm{M}^{-1} \mathrm{~cm}^{-1}$ at both bands. The mol equivalents of $\mathrm{V}^{\mathrm{IV}} \mathrm{O}^{2+}$ added are indicated. Measurements were carried out in HEPES-S buffer ( $\mathrm{pH}=7.4$ ) with an albumin concentration of $\sim 650 \mu \mathrm{M}$. For the first additions of $\mathrm{V}^{\mathrm{IV}} \mathrm{O}^{2+}$ (1:0.29 and 1:0.59 molar ratios, not included) the CD signal at ca. $720-900 \mathrm{~nm}$ are slightly positive.

is measured is the sum of the CD signals corresponding to all complexes formed [50-57].

The zinc primary binding site (the MBS site) is at the interface of domains I and II of HSA. In the presence of fatty acids this site is disrupted, and the bound $\mathrm{Zn}^{\mathrm{II}}$ at this site decreases drastically in the presence of long chain fatty acids. This disruption is caused by a domain-domain movement that can be described as a rotation of domain I with respect to domain II [29-32]. As a general remark to the spectra of Figure 1 we may emphasize that the $\mathrm{CD}$ spectra measured with solutions containing dHSA and $\mathrm{V}^{\mathrm{IV}} \mathrm{O}^{2+}$ are more intense than those with solutions containing fHSA and $\mathrm{V}^{\mathrm{IV}} \mathrm{O}^{2+}$. This is an indication that some of the vanadium binding sites also involve residues of the MBS site, the measured $|\Delta \varepsilon|$ values in the visible range being significantly lower in the case of fHSA- $\mathrm{V}^{\mathrm{IV}} \mathrm{O}^{2+}$ solutions.
Figure 2 shows the changes in the visible CD spectra of titration of fHSA with 0.8-8.9 mol equivalents of $\mathrm{V}^{\mathrm{IV}} \mathrm{O}^{2+}$. The measured CD spectra are the result of the sum of all CD bands present, some with $\Delta \varepsilon>0$, others with $\Delta \varepsilon<0$, due to the several chiral $\mathrm{V}^{\mathrm{IV}} \mathrm{O}$-complexes being formed. Therefore the resulting $\mathrm{CD}$ band pattern and its changes as $\mathrm{V}^{\mathrm{IV}} \mathrm{O}$ is added may be complex.

Up to 0.88 mol equivalent of $\mathrm{V}^{\mathrm{IV}} \mathrm{O}^{2+}$ added to the fHSA, the intensity of the $\mathrm{CD}$ signals are very low, but at ca. $830 \mathrm{~nm}$ the $\Delta \varepsilon$ are $>0$. When $>1$ mol equivalent of $\mathrm{V}^{\mathrm{IV}} \mathrm{O}^{2+}$ have been added the $\mathrm{CD}$ signals at ca. $830 \mathrm{~nm}$ become negative and the $|\Delta \varepsilon|$ values increase with $\mathrm{V}^{\mathrm{IV}} \mathrm{O}^{2+}$ concentration. Chasteen, Orvig and Sanna [1, 26, 36, 39] obtained EPR spectra in agreement with $\mathrm{V}^{\mathrm{IV}} \mathrm{O}^{2+}$ exhibiting two types of binding modes of which one is considered non-specific. Our group recently discussed metal competition studies of $\mathrm{Cu}(\mathrm{II})$ and $\mathrm{Zn}$ (II) as metal probes for $\mathrm{V}^{\mathrm{IV}} \mathrm{O}^{2+}$ binding with HSA [37]. These studies confirmed the involvement of amino acid side chains of the ATCUN and MBS sites. In this work we also examine the metal competition studies of $\mathrm{Cu}(\mathrm{II})$ and $\mathrm{Zn}(\mathrm{II})$ as metal probes with $\mathrm{V}^{\mathrm{IV}} \mathrm{O}^{2+}$ binding with BSA and PSA.

\section{Studies with defatted BSA and $\mathrm{V}^{\mathrm{IV}} \mathrm{O}^{2+}$}

BSA, like HSA, was reported to have two binding sites for metals. One site is the MBS which is the principal binding site, while the second site is the site $\mathrm{B}$ or $\mathrm{Cd}^{2+}$ primary site [30]. The $C D$ spectra in the visible range observed after titrating 0.45 $\mathrm{mM}$ of BSA (defatted) with increasing mol equivalents ( 0.6 to 4) of $\mathrm{V}^{\mathrm{IV}} \mathrm{O}$ showed positive and negative features similar to $\left(\mathrm{V}^{\mathrm{IV}} \mathrm{O}\right)_{\mathrm{m}} \mathrm{HSA}$ CD spectra (Fig. 3b). Two main bands, positive $(\sim 588 \mathrm{~nm})$ and negative $(\sim 832 \mathrm{~nm})$, showed up which globally increase in intensity with increasing $\mathrm{V}^{\mathrm{IV}} \mathrm{O}^{2+}$ concentration (Fig. $3 \mathrm{a}$ ), but other $\mathrm{CD}$ bands are detected, e.g. at $\lambda<400 \mathrm{~nm}$, at $\lambda_{\max }$ $\approx 700 \mathrm{~nm}$ and at $\lambda_{\max }>950 \mathrm{~nm}$. As for the HSA- $\mathrm{V}^{\mathrm{IV}} \mathrm{O}$ system the $\mathrm{CD}$ band pattern is complex and changes upon addition of $\mathrm{V}^{\mathrm{IV}} \mathrm{OSO}_{4}$. The type of spectra obtained at low $\mathrm{V}^{\mathrm{IV}} \mathrm{O}$ :HSA molar ratios (up to 2:1) differ from those obtained at higher molar ratios, e.g. 4:1. Thus different sites are occupied as $\mathrm{V}^{\mathrm{IV}} \mathrm{O}^{2+}$ is progressively added to the defatted BSA.

Yasui et al. [34] also observed positive $C D$ with $\lambda_{\max }$ at $\sim 590 \mathrm{~nm}$ when $0.5 \mathrm{mM}$ BSA was titrated with $0-1.5 \mathrm{mM}$ $\mathrm{V}^{\mathrm{IV}} \mathrm{O}^{2+}$ at $\mathrm{pH}$ of 7.4. However, the spectra they obtained do not coincide with those obtained here, and no measurements were made for $\lambda>800 \mathrm{~nm}$.

As for the studies with fatted/defatted HSA and $\mathrm{V}^{\mathrm{IV}} \mathrm{O}^{2+}$, the EPR spectra of the solutions of Figure 3 agree when simulated as consisting of two types of signals. The parameters of $\mathrm{V}^{\mathrm{IV}} \mathrm{O}^{2+}$ occupying VBS2 are: $A_{z}=167.6 \times 10^{-4} \mathrm{~cm}^{-1}$ and $\mathrm{g}_{\mathrm{z}}=$ 1.940. The $A_{\mathrm{z}}$ and $\mathrm{g}_{\mathrm{z}}$ values obtained for $\mathrm{V}^{\mathrm{IV}} \mathrm{O}^{2+}$ binding to the VBS2 on BSA are close to those obtained for fatted/defatted HSA and $\mathrm{V}^{\mathrm{IV}} \mathrm{O}^{2+}$, and agree with those reported by Orvig [1] and Sanna [36].

Incremental additions of $\mathrm{Zn}^{\mathrm{II}}$ ions to solutions containing 4 mol equiv of $\mathrm{V}^{\mathrm{IV}} \mathrm{O}$ decrease the intensities of the bands at $\sim 830$ $\mathrm{nm}$ and $\sim 588 \mathrm{~nm}$ (Figure SI-1). This means that $\mathrm{Zn}^{2+}$ displaces 


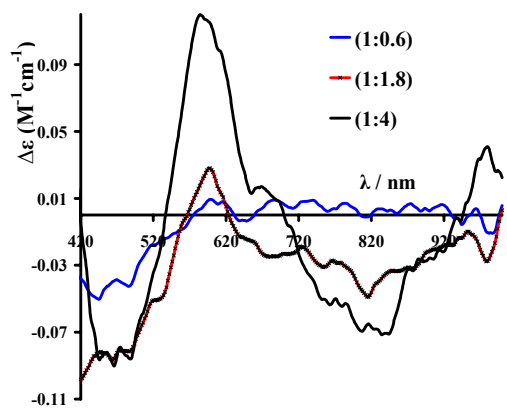

a

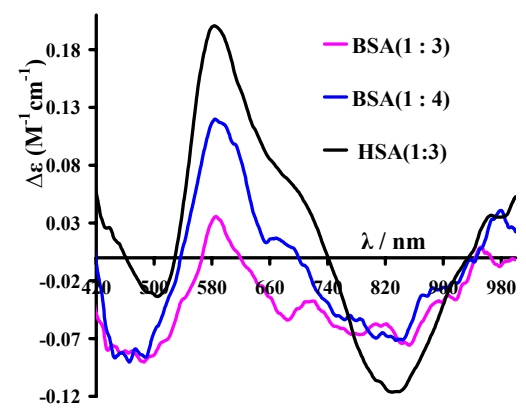

b

Fig. 3. (a) CD spectra of solutions containing $0.45 \mathrm{mM}$ of dBSA and $\mathrm{V}^{\mathrm{IV}} \mathrm{OSO}_{4}$; (b) $0.45 \mathrm{mM}$ dBSA and $\mathrm{V}^{\mathrm{IV}} \mathrm{OSO}_{4}$ and $1 \mathrm{mM}$ dHSA and $\mathrm{V}^{\mathrm{IV}} \mathrm{O}$ $\mathrm{SO}_{4}$. The mol ratios of BSA: $\mathrm{V}^{\mathrm{IV}} \mathrm{O}$ and HSA: $\mathrm{V}^{\mathrm{IV}} \mathrm{O}$ are indicated. The spectral patterns are similar. Measurements were carried out in HEPES-S buffer $(\mathrm{pH}=7.4)$ with an optical path of $5 \mathrm{~cm}$.

the $\mathrm{V}^{\mathrm{IV}} \mathrm{O}$-species responsible for the $\sim 588$ and $\sim 830 \mathrm{~nm}$ bands. As $\mathrm{Zn}^{2+}$ binds to the MBS site of BSA, these $\mathrm{V}^{\mathrm{IV}} \mathrm{O}$-complexes were probably bound close to the MBS residues.

The EPR spectra shown in Figure 4 indicate that some $\mathrm{V}^{\mathrm{IV}} \mathrm{O}^{2+}$ remained bound to dBSA when $\mathrm{Zn}^{\mathrm{II}}$ was added; in fact the $\mathrm{V}^{\mathrm{IV}} \mathrm{O}$ EPR signals are still observable after addition of 3 mol equivalents of $\mathrm{Zn}^{\mathrm{II}}$. Only one type of signal is observed in the three spectra, but the peaks decrease in intensity with the amount of $\mathrm{Zn}^{\mathrm{II}}$ added. At $\mathrm{pH} 7.4$ the $\mathrm{V}^{\mathrm{IV}} \mathrm{O}^{2+}$ displaced by $\mathrm{Zn}^{2+}$ either precipitates as $\mathrm{V}^{\mathrm{IV}} \mathrm{O}(\mathrm{OH})_{2}$, or forms EPR-silent $\left[\left(\mathrm{V}^{\mathrm{IV}} \mathrm{O}\right)(\mathrm{OH})_{5}^{-}\right]_{\mathrm{n}}$, or oxidizes to $\mathrm{V}^{\mathrm{V}}$, and the $\mathrm{V}^{\mathrm{IV}} \mathrm{O}$ EPR signal detected after addition of $\mathrm{Zn}^{\mathrm{II}}$ is thus not due to $\mathrm{V}^{\mathrm{IV}} \mathrm{O}$ bound to the MBS site. This binding yields weak CD signals for $\lambda>520$ $\mathrm{nm}$ and the EPR signals are either due to $\mathrm{V}^{\mathrm{IV}} \mathrm{O}^{2+}$ bound to the ATCUN site (as suggested in [37]) and/or to $\mathrm{V}^{\mathrm{IV}} \mathrm{O}^{2+}$ bound to other sites, e.g. accessible $\mathrm{N}$-imidazole atoms of His residues or O-carboxylate atoms of Asp or Glu residues.

\section{Studies with fatted PSA and $\mathrm{V}^{\mathrm{IV}} \mathrm{O}^{2+}$}

Further studies to determine the binding site on HSA were carried out with fatted PSA. PSA lacks His-3 residue which is required for the formation of the ATCUN motif, the primary binding site of $\mathrm{Cu}^{\mathrm{II}}$ on HSA and BSA. As stated above and in the SI section, PSA differs from HSA and BSA in several aspects, namely the substitution of His-3 by Tyr-3. Thus the $\mathrm{N}$-terminal strong $\mathrm{Cu}^{\mathrm{II}}$ and $\mathrm{Ni}^{\mathrm{II}}$ binding site (ATCUN) does not exist in PSA [27, 30, 34]. The MBS however is preserved in PSA [31]. PSA also has two more His residues than the 16 in both HSA and BSA. Additionally, PSA binds $\mathrm{Zn}^{\mathrm{II}}$ and $\mathrm{Cd}^{\mathrm{II}}$ at the MBS site much more strongly than HSA and BSA [34].

The spectra shown in Figure 5 indicate that when $\mathrm{V}^{\mathrm{IV}} \mathrm{O}^{2+}$ was progressively added to $\sim 630 \mu \mathrm{M}$ fatted PSA the CD band pattern obtained in the visible range totally differs from those of HSA and BSA, as is also emphasized in Figure 6. Two types of CD spectra may be considered. The first type forms, up to $1: 1$ ( $\mathrm{V}^{\mathrm{IV}} \mathrm{O}: \mathrm{PSA}$ ), two isodichroic points being observed: (i) at $\lambda \approx$ $638 \mathrm{~nm}$ and $\Delta \varepsilon \approx-0.0074 \mathrm{M}^{-1} \mathrm{~cm}^{-1}$ and (ii) at $\lambda=\sim 760 \mathrm{~nm}$ and $\Delta \varepsilon \approx-0.013 \mathrm{M}^{-1} \mathrm{~cm}^{-1}$. The second type of CD spectra involves at least two species: one forming up to $1: 3\left(\mathrm{~V}^{\mathrm{IV}} \mathrm{O}: \mathrm{PSA}\right)$ with a

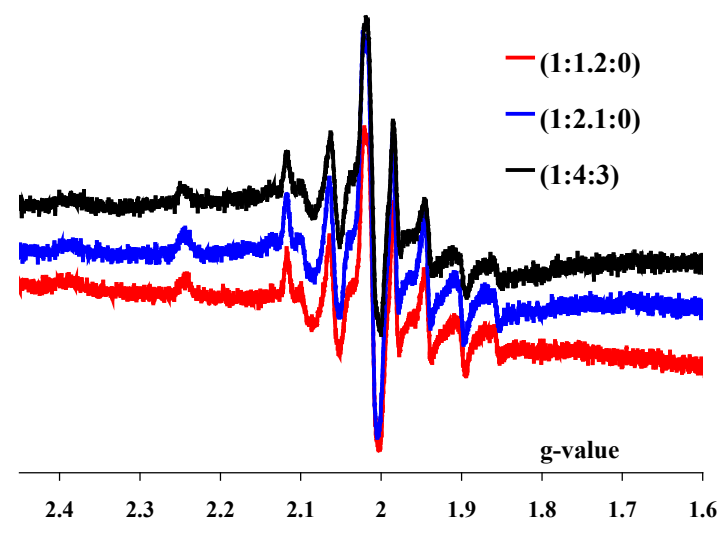

Fig. 4. $1^{\text {st }}$ derivative X-band EPR spectra of frozen solutions (at $77 \mathrm{~K}$ ) in HEPES-S buffer ( $\mathrm{pH} 7.4$ ) containing $0.45 \mathrm{mM}$ BSA (defatted) and with BSA: $\mathrm{V}^{\mathrm{IV}} \mathrm{O}^{2+}: \mathrm{Zn}(\mathrm{II})$ ratios of 1:1.2:0, 1:2.1:0 and 1:4:3.

$\lambda_{\max }$ at $\approx 525 \mathrm{~nm}$ and $\Delta \varepsilon \approx-0.07 \mathrm{M}^{-1} \mathrm{~cm}^{-1}$, and the remaining one at higher mol amounts of $\mathrm{V}^{\mathrm{IV}} \mathrm{O}^{2+}$ (Figure 5), with increase of the $|\Delta \varepsilon|$ values of the bands at $\lambda \approx 580$ and $700 \mathrm{~nm}$, decrease of the $|\Delta \varepsilon|$ values at $\approx 525 \mathrm{~nm}$ and shift to the red of the $\lambda_{\max }$ of the band at ca. $850-900 \mathrm{~nm}$. At least two isodichroic points are visible: (i) at $\lambda=\sim 658 \mathrm{~nm}$ and $\Delta \varepsilon=\sim-0.07 \mathrm{M}^{-1} \mathrm{~cm}^{-1}$; and (ii) at $\lambda \approx 680 \mathrm{~nm}$ and $\Delta \varepsilon \approx-0.08 \mathrm{M}^{-1} \mathrm{~cm}^{-1}$.

Upon addition of $1-2$ mol equivalents of $\mathrm{Zn}^{\mathrm{II}}$ to a solution with a $\mathrm{V}^{\mathrm{IV}} \mathrm{O}^{2+}$ :PSA molar ratio of 6:1 (Figure SI-2), the intensity of the bands at $\sim 524 \mathrm{~nm}$ and $\sim 590 \mathrm{~nm}$ decreased. However, it appears that $\mathrm{Zn}^{\mathrm{II}}$ does not interfere much with the sites responsible for the bands at 700 and $880 \mathrm{~nm}$.

The $\left(\mathrm{V}^{\mathrm{IV}} \mathrm{O}\right)_{\mathrm{m}} \mathrm{PSA}(\mathrm{m}=1,2,6)$ EPR spectra depicted in Figure 7 show that the resonant field positions of all samples are the same even after addition of $\mathrm{Zn}^{\mathrm{II}}$. This suggests that only one type of binding set is present [with spin Hamiltonian parameters: $A_{z}=165.9 \times 10^{-4} \mathrm{~cm}^{-1}$ and $\left.\left.g_{\mathrm{z}}=1.941\right\}\right]$. Note that if a 'strong site' similar to the one for HSA exists, it will not be readily observable in the X-band EPR spectrum at $\mathrm{pH}$ 7.4. The effect of $\mathrm{Zn}^{\mathrm{II}}$ on the binding of $\mathrm{V}^{\mathrm{IV}} \mathrm{O}^{2+}$ to PSA may be seen by the decrease in intensity and linewidths of the EPR spectrum of the solution containing 3 mol equivalents of $\mathrm{Zn}^{\mathrm{II}}$ (1:6:3). This 


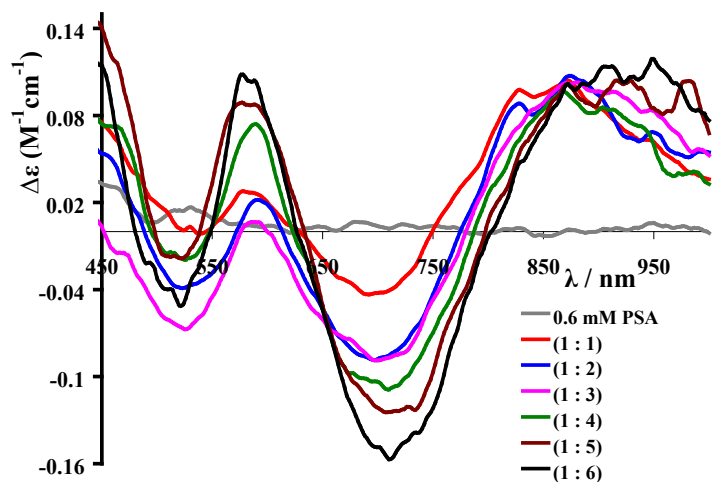

Fig. 5. CD spectra of a $0.63 \mathrm{mM}$ solution of fPSA (fatted) in HEPES-S buffer $(\mathrm{pH}=7.4)$ and upon successive additions of 1 to $6 \mathrm{~mol}$ equivalents of $\mathrm{V}^{\mathrm{IV}} \mathrm{O}^{2+}$. The measurements were carried out with an optical path of $5 \mathrm{~cm}$.

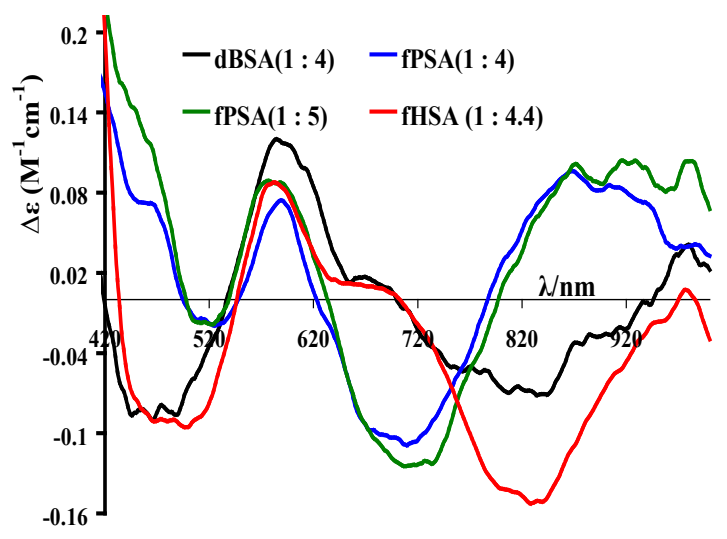

Fig. 6. Comparison of the $\mathrm{CD}$ spectral patterns of the $\mathrm{V}^{\mathrm{IV}} \mathrm{O}$-complexes formed with defatted BSA (dBSA), fatted PSA (fPSA) and fatted HSA (fHSA). All spectra were recorded with solutions in HEPES-S buffer ( $\mathrm{pH} 7.4)$ and with an optical path of $5 \mathrm{~cm}$. [dBSA] $=0.45 \mathrm{mM}$; $[\mathrm{fPSA}]=0.63 \mathrm{mM} ;[\mathrm{fHSA}]=0.70 \mathrm{mM}$. The molar ratios of $\left(\mathrm{V}^{\mathrm{IV}} \mathrm{O}^{2+}\right.$ : albumin) are indicated.

together with the decrease in intensities observed in some bands of the visible $\mathrm{CD}$ experiments show that $\mathrm{Zn}^{\mathrm{II}}$ partly displaces $\mathrm{V}^{\mathrm{IV}} \mathrm{O}^{2+}$ from some of its sites, but in a way quite distinct from HSA or BSA. This also indirectly shows that the $\mathrm{V}^{\mathrm{IV}} \mathrm{O}$ binding at HSA or BSA certainly also involves amino acid residues of the ATCUN site. Finally, the observation of rather strong EPR signals in solutions containing 1:6:3 (PSA: $\mathrm{V}^{\mathrm{IV}} \mathrm{O}: \mathrm{Zn}^{\mathrm{II}}$ ) molar ratios, indicates that a significant amount of $\mathrm{V}^{\mathrm{IV}} \mathrm{O}^{2+}$ ions are bound to sites other than the ATCUN (not present in PSA), or the MBS sites. These sites may be e.g. accessible N-imidazole atoms of His residues or O-carboxylate atoms of Asp or Glu residues, but the observation of rather strong $C D$ signals due to this type of binding suggests that at least two protein donor atoms are bound to the $\mathrm{V}^{\mathrm{IV}} \mathrm{O}$ centers at these sites. The presence of a $3^{\text {rd }}$ type of site was previously suggested for $\mathrm{Cu}^{\mathrm{II}}$ binding to PSA [31].

Judging from the EPR parameters in Table 1, the binding set of $\mathrm{V}^{\mathrm{IV}} \mathrm{O}^{2+}$ in HSA and BSA are quite similar to each other, while those with PSA may differ slightly. Comparatively, the

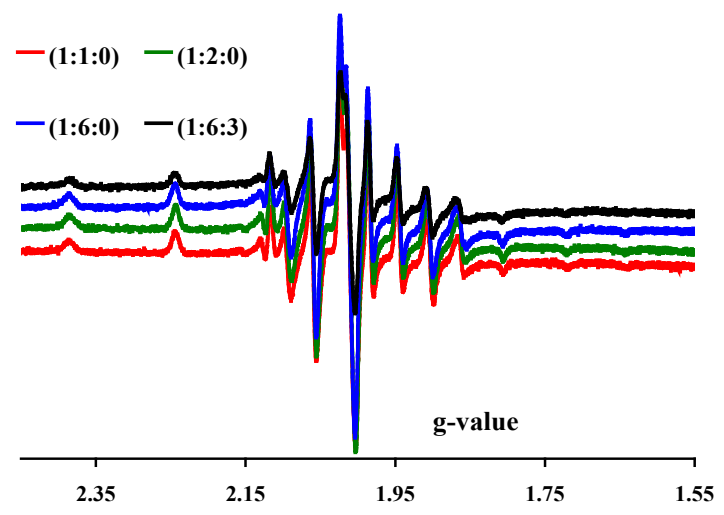

Fig. 7. First derivative $X$-band EPR spectra of frozen solutions (77 $\mathrm{K})$ of fPSA in HEPES-S buffer (pH 7.4) containing PSA: $\mathrm{V}^{\mathrm{IV}} \mathrm{O}: \mathrm{Zn}^{\mathrm{II}}$ molar ratios of $1: 1: 0 ; 1: 2: 1$; and $1: 6: 3$. The concentration of PSA is $\sim 0.63 \mathrm{mM}$.

Table 1. EPR spin-Hamiltonian parameters of $\mathrm{V}^{\mathrm{IV}} \mathrm{O}$-albumin species obtained at $\mathrm{pH} 7.4$ in the presence of $\mathrm{Zn}^{\mathrm{II}}$.

\begin{tabular}{ccc}
\hline System & $g_{z}$ & $A_{\mathrm{z}}\left(\times 10^{4} \mathrm{~cm}^{-1}\right)$ \\
\hline $\mathrm{V}^{\mathrm{IV}} \mathrm{O}^{2+}+\mathrm{dHSA}+\mathrm{Zn}^{\mathrm{II}}$ & 1.941 & 167.9 \\
$\mathrm{~V}^{\mathrm{IV}} \mathrm{O}^{2+}+\mathrm{fHSA}+\mathrm{Zn}{ }^{\mathrm{II}}$ & 1.941 & 167.8 \\
$\mathrm{~V}^{\mathrm{IV}} \mathrm{O}^{2+}+\mathrm{dBSA}+\mathrm{Zn}{ }^{\mathrm{II}}$ & 1.940 & 167.6 \\
$\mathrm{~V}^{\mathrm{IV}} \mathrm{O}^{2+}+\mathrm{fPSA}+\mathrm{Zn}^{\mathrm{II}}$ & 1.941 & 165.9 \\
\hline
\end{tabular}

$A_{\mathrm{Z}}$ values of the $\mathrm{V}^{\mathrm{IV}} \mathrm{O}$-PSA species are slightly lower than the $\sim 167 \times 10^{-4} \mathrm{~cm}^{-1}$ obtained for $\mathrm{V}^{\mathrm{IV}} \mathrm{O}^{2+}$ binding to HSA and BSA. The difference is small but significant. Thus it is probable that the binding of $\mathrm{V}^{\mathrm{IV}} \mathrm{O}^{2+}$ in PSA at the VBS2 is not exactly the same as in HSA and BSA: the differences in spin-Hamiltonian parameters either reflect variations in the amino acid residues involved in the $\mathrm{V}^{\mathrm{IV}} \mathrm{O}$ binding site on PSA and/or changes in their orientation.

Further studies to determine the binding site on HSA were carried out with fatted PSA.

Bal et al. [31] reported that titration of $0.67 \mathrm{mM}$ PSA solution with $\mathrm{Cu}^{\mathrm{II}}$ ions at $\mathrm{pH} 7.4$ yielded only 'one' positive band between 500 and $800 \mathrm{~nm}$ : (i) at $\lambda_{\max } \approx 670 \mathrm{~nm}$ for $\sim 1$ mol equivalent of $\mathrm{Cu}^{\mathrm{II}}$ added, and (ii) at $\lambda_{\max } \approx 650 \mathrm{~nm}$ for $\sim 2$ mol equivalent of $\mathrm{Cu}^{\mathrm{II}}$. Contrary to these findings we observed only one positive band between 500 and $\sim 900 \mathrm{~nm}$ with $\lambda_{\max } \approx$ $650 \mathrm{~nm}$ when a $0.60 \mathrm{mM}$ fPSA solution was titrated with either $\sim 1$ and $\sim 2$ mol equivalents of $\mathrm{Cu}^{\mathrm{II}}$ solution (Figure SI-3). It is not clear why this was so. Positive bands also appeared below ca. $500 \mathrm{~nm}$.

Yasui et al. [34] reported that upon titration of PSA with $\mathrm{V}^{\mathrm{IV}} \mathrm{O}^{2+}$ they observed a positive band at $590 \mathrm{~nm}$, but no figure was presented; when the resulting solution was titrated with a $\mathrm{Cu}^{\mathrm{II}}$ solution a positive band at $690 \mathrm{~nm}$ developed. By implication, they attributed the band at $690 \mathrm{~nm}$ to $\mathrm{Cu}^{\mathrm{II}}$ binding to its site on PSA [34]. These authors did not specify whether fatted or defatted PSA was used (presumably it was fatted PSA).

Our CD spectra were obtained with a red-sensitive photomultiplier, thus allowing recording the CD signal up to 1000 
$\mathrm{nm}$. When $0.60 \mathrm{mM}$ fPSA was titrated with 0.5 to 5 mol equivalents of $\mathrm{V}^{\mathrm{IV}} \mathrm{O}^{2+}$, four bands were observed in the $500-1000 \mathrm{~nm}$ region, Figure 8 . The bands have $\lambda_{\max }$ at $\sim 525 \mathrm{~nm}(\Delta \varepsilon<0)$, $\sim 590 \mathrm{~nm}(\Delta \varepsilon>0), \sim 700 \mathrm{~nm}(\Delta \varepsilon<0)$ and $\sim 860 \mathrm{~nm}(\Delta \varepsilon>0)$. The appearance of the band at $\sim 590 \mathrm{~nm}$ is in agreement with the $\sim 590 \mathrm{~nm}$ band observed by Yasui et al. [34].

Considering the CD spectra depicted in Figure 8, it is predicted that the positive $\mathrm{CD}$ band at $500-800 \mathrm{~nm}$ for the $\mathrm{Cu}-\mathrm{PSA}$ species may overlap with the $(-,+,-)$ band pattern observed for the $\mathrm{V}^{\mathrm{IV}} \mathrm{O}-\mathrm{PSA}$ species. Hence, if to a solution containing PSA and $\mathrm{Cu}^{\mathrm{II}}$ a solution containing $\mathrm{V}^{\mathrm{IV}} \mathrm{O}^{2+}$ is added, changes will be observed in the $\mathrm{CD}$ spectra that will depend on the relative amount of $\mathrm{Cu}^{\mathrm{II}}$ and $\mathrm{V}^{\mathrm{IV}} \mathrm{O}$ and on the binding strength of $\mathrm{Cu}^{\mathrm{II}}$ and $\mathrm{V}^{\mathrm{IV}} \mathrm{O}$ to each binding site at PSA.

Addition of 1 and 2 mol equivalents of $\mathrm{Cu}^{\mathrm{II}}$ to a solution $0.60 \mathrm{mM}$ fPSA at $\mathrm{pH} 7.4$ resulted in the appearance of CD spectra with $\lambda_{\max }$ at $\sim 650 \mathrm{~nm}$ (e.g. Figures 8,9 or SI-3). Upon addition of incremental mol equivalents of $\mathrm{V}^{\mathrm{IV}} \mathrm{O}^{2+}$, Figure 10, changes are observed. Namely the intensity of the $\mathrm{Cu}_{2} \mathrm{PSA} C D$ band decreased to about $50 \%$ after addition of 1 mol equiva-

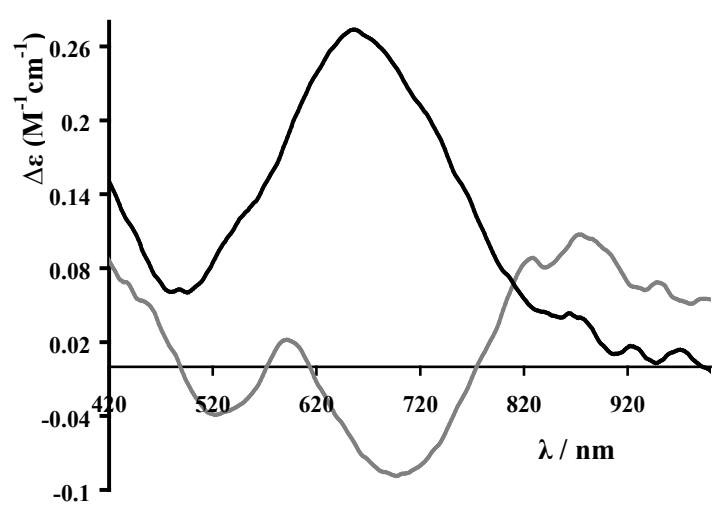

Fig. 8. Comparison of the spectra of solutions containing fPSA and either $\mathrm{Cu}^{\mathrm{II}}$ or $\mathrm{V}^{\mathrm{IV}} \mathrm{O}$. (-): fPSA and $\mathrm{V}^{\mathrm{IV}} \mathrm{O}$ with fPSA:M molar ratio of 1:2; (-): fPSA and $\mathrm{Cu}^{\mathrm{II}}$ with fPSA:M molar ratio of 1:2. Measurements were carried out in HEPES-S buffer $(\mathrm{pH}=7.4)$.

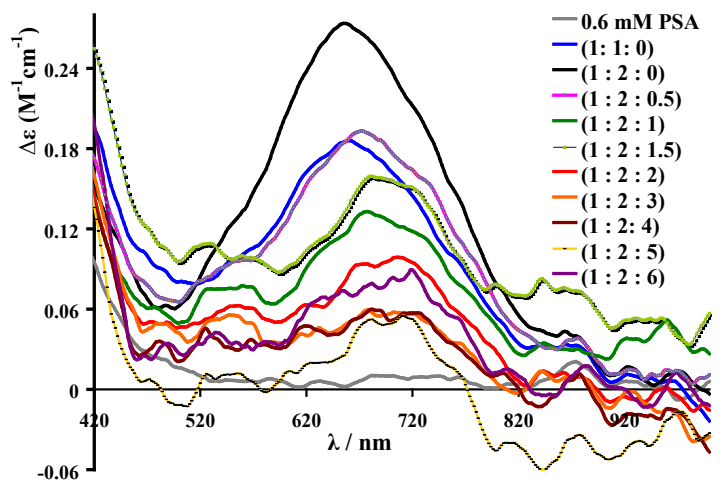

Fig. 9. $\mathrm{CD}$ spectra of a solution containing fPSA $(0.60 \mathrm{mM})$, and after additions of 1 and 2 mole equivalents of $\mathrm{Cu}^{\mathrm{II}}$ ions, and subsequent titration of this solution with $\mathrm{V}^{\mathrm{IV}} \mathrm{O}\left(\mathrm{ClO}_{4}\right)_{2}(9.90 \mathrm{mM})$. The mol equivalents of added $\mathrm{V}^{\mathrm{IV}} \mathrm{O}\left(\mathrm{ClO}_{4}\right)_{2}$ are indicated. Measurements were carried out in HEPES-S buffer $(\mathrm{pH}=7.4)$. lent of $\mathrm{V}^{\mathrm{IV}} \mathrm{O}^{2+}$. Further additions of $\mathrm{V}^{\mathrm{IV}} \mathrm{O}^{2+}$ resulted in further decrease in the intensity of the $\mathrm{Cu}_{2}$ PSA band.

The decrease in intensity of the $\mathrm{CD}$ band due to the $\mathrm{Cu}-$ PSA species as $\mathrm{V}^{\mathrm{IV}} \mathrm{O}^{2+}$ is added indicates the displacement of $\mathrm{Cu}^{\mathrm{II}}$ from the MBS site of PSA. Also there is a shift in the $\lambda_{\max }$ from $650 \mathrm{~nm}$ to $\sim 690 \mathrm{~nm}$ as new species form, this being in agreement with the observation of Yasui et al. [34] who observed the appearance of the $\sim 690 \mathrm{~nm}$ band after addition of $\mathrm{Cu}^{\mathrm{II}}$ solution to solutions containing PSA and $\mathrm{V}^{\mathrm{IV}} \mathrm{O}^{2+}$. However, it is clear that the $\mathrm{CD}$ signals recorded have contributions from several $\mathrm{V}^{\mathrm{IV}} \mathrm{O}-\mathrm{PSA}$ and $\mathrm{Cu}^{\mathrm{II}}$-PSA species, as may be inferred from Figure 9.

Figure 10a was obtained by subtracting the CD spectra of solutions containing PSA and $\mathrm{Cu}^{\mathrm{II}}$ at 2:1 $\mathrm{Cu}(\mathrm{II})$ :PSA molar ratio\} from those of the solutions containing PSA, $\mathrm{Cu}^{\mathrm{II}}$ and incremental additions of $\mathrm{V}^{\mathrm{IV}} \mathrm{O}^{2+}$ (Figure 9). This gives a 'measure' of the displacement of the $\mathrm{Cu}^{2+}$ ions from fPSA by the $\mathrm{V}^{\mathrm{IV}} \mathrm{O}^{2+}$ added. When the experimental CD spectra shown in Figure 10 were subtracted from the corresponding sum of $\mathrm{Cu}_{2} \mathrm{PSA}$ and $\left(\mathrm{V}^{\mathrm{IV}} \mathrm{O}\right)_{\mathrm{m}}$-PSA $(\mathrm{m}=1,2,3,4,5,6)$, the spectra shown in Figure $10 \mathrm{~b}$ were obtained. The patterns shown in Figure 10b resemble the spectra shown in Figure 5. This gives further proof that, besides substituting $\mathrm{Cu}^{\mathrm{II}}$ at the MBS binding site, $\mathrm{V}^{\mathrm{IV}} \mathrm{O}^{2+}$ appears to bind sites not previously occupied by $\mathrm{Cu}^{\mathrm{II}}$.

In Figure SI-4 apparently only the $\mathrm{Cu}^{\mathrm{II}}$ spectrum with one resonant field position is observed in the $\mathrm{X}$-band EPR spectrum of the frozen solutions containing $\mathrm{Cu}_{2} \mathrm{HSA}+\mathrm{V}^{\mathrm{IV}} \mathrm{O}^{2+}$ in the molar ratios indicated. The corresponding EPR parameters are: $A_{\mathrm{z}}=174.0 \times 10^{-4} \mathrm{~cm}^{-1}$ and $\mathrm{g}_{\mathrm{z}}=2.27$. These values differ from those reported by Bal et al. [31] for $\mathrm{Cu}^{\mathrm{II}}$ binding to PSA: (1) $A_{\mathrm{z}}=188 \times 10^{-4} \mathrm{~cm}^{-1}$ and $\mathrm{g}_{\mathrm{z}}=2.26$ for a site designated as I, and (2) $A_{\mathrm{z}}=184 \times 10^{-4} \mathrm{~cm}^{-1}$ and $\mathrm{g}_{\mathrm{z}}=2.29$ to site II (the MBS site). The EPR signals of $\mathrm{V}^{\mathrm{IV}} \mathrm{O}$-species are not clearly seen, although from the $\mathrm{CD}$ spectra it is clear that it partly displaced $\mathrm{Cu}^{2+}$ from PSA. A rather similar situation was also found in the case of the $\mathrm{Cu}^{\mathrm{II}}-\mathrm{V}^{\mathrm{IV}} \mathrm{O}-\mathrm{HSA}$ system [37]. This suggests that a significant part of the $\mathrm{V}^{\mathrm{IV}} \mathrm{O}$ species bind HSA and PSA at these sites forming EPR-silent species (but active in CD).

\section{$\left(\mathrm{V}^{\mathrm{IV}} \mathrm{O}\right)_{\mathrm{m}} \mathrm{HSA}$ interaction with maltol}

To gain more insight into the possible interaction of $\mathrm{V}^{\mathrm{IV}} \mathrm{O}^{2+}$ with maltol in blood plasma in circulation, studies were carried out by titrating $\mathrm{V}^{\mathrm{IV}} \mathrm{O}^{2+}$-HSA complexes with BMOV and maltol, and monitoring the interaction by $\mathrm{CD}$ and EPR. Some of these results were reported recently [37].

When $0.67 \mathrm{mM}\left(\mathrm{V}^{\mathrm{IV}} \mathrm{O}\right)_{0.9} \mathrm{HSA}$ (fatted) was titrated with 0.2-2.6 mole equivalents of maltol, the CD spectra depicted in Figure 11a were obtained. Very clear changes are seen in the CD spectra in the visible region upon addition of maltol, particularly in the $650-1000 \mathrm{~nm}$ range, but changes are also observed in the bands at $\lambda<650 \mathrm{~nm}$. Other experiments but starting with different $\mathrm{V}^{\mathrm{IV}} \mathrm{O}$ :HSA ratios are also shown in Figure 12. Globally the type of spectra recorded differ from those of solutions containing $\mathrm{V}^{\mathrm{IV}} \mathrm{O}$ and HSA, clearly demonstrating that the coordination environment of $\mathrm{V}^{\mathrm{IV}} \mathrm{O}^{2+}$ bound to HSA is modified when maltol is added to the system. 

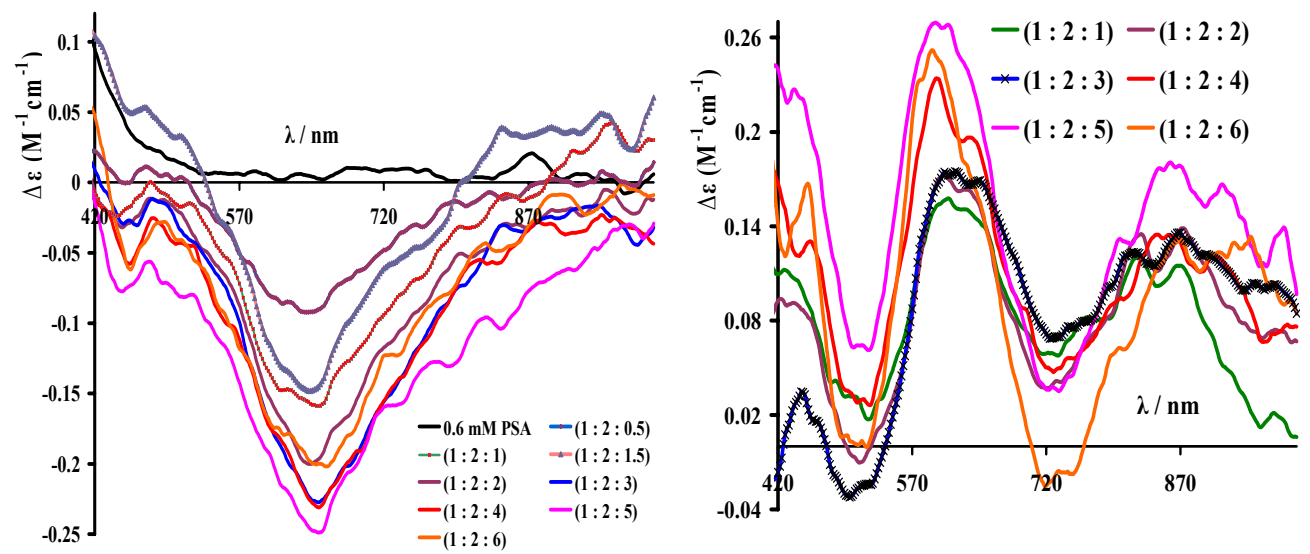

Fig. 10. (a) CD spectral difference obtained by subtracting the $\mathrm{Cu}_{2}$ PSA CD spectra of the solution containing PSA and $\mathrm{Cu}$ (II $(1: 2)$ from those of $\left(\mathrm{Cu}_{2} \mathrm{PSA}+\mathrm{mV}^{\mathrm{IV}} \mathrm{O}^{2+}\right.$, Figure 12). (b) The spectral difference was obtained by subtracting the $\mathrm{CD}$ spectra of the solutions $\left(\mathrm{Cu}_{2} \mathrm{PSA}+\mathrm{mV}^{\mathrm{IV}} \mathrm{O}^{2+}\right)$ of Figure 12 from the corresponding sums of $\left(\mathrm{Cu}_{2} \mathrm{PSA}\right.$ and $\left(\mathrm{V}^{\mathrm{IV}} \mathrm{O}\right)_{\mathrm{m}} \mathrm{PSA}(\mathrm{m}=1,2,3,4,5,6)$. Measurements were carried out in HEPES-S buffer $(\mathrm{pH}=7.4)$.
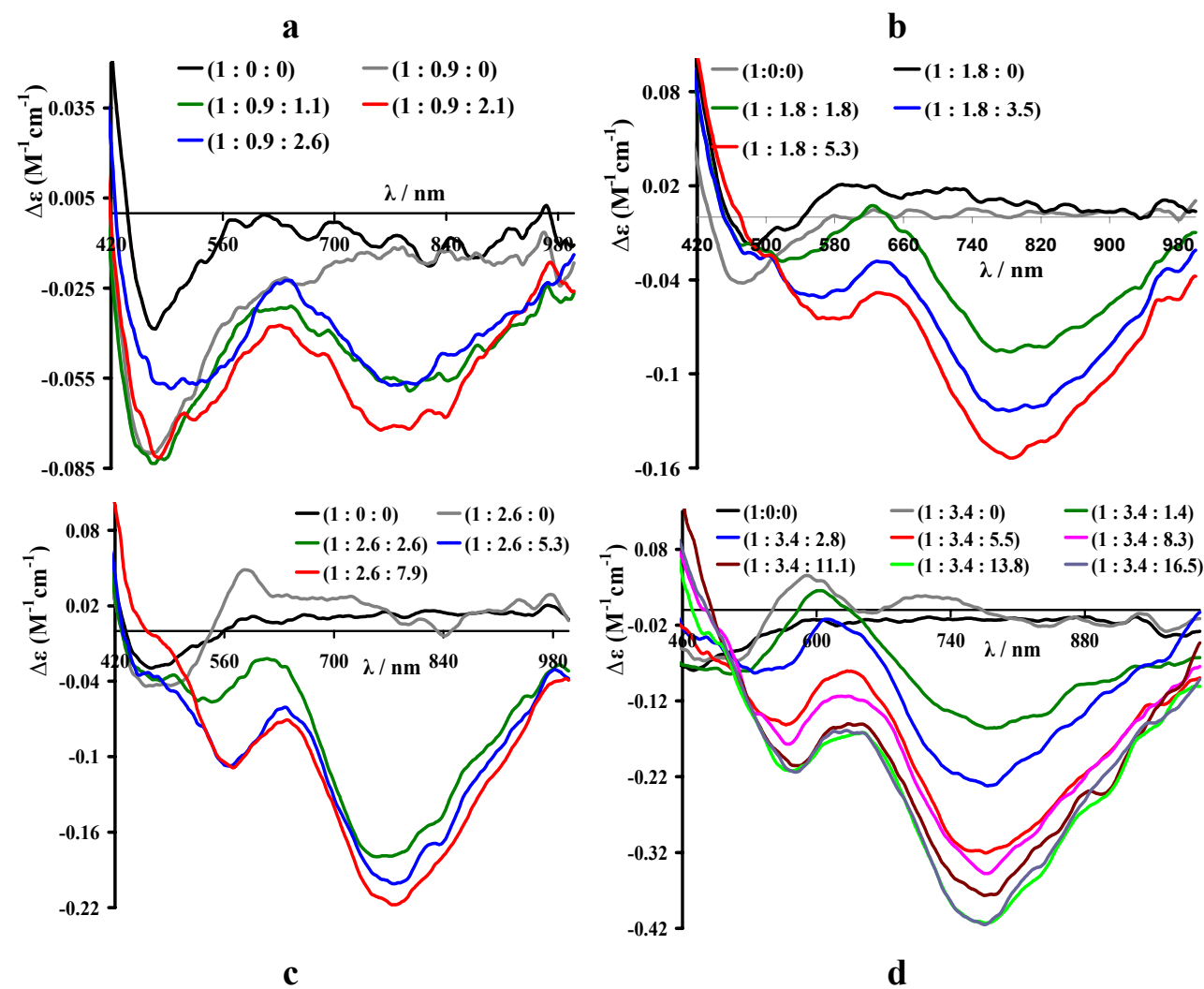

Fig. 11. CD spectra recorded upon several distinct titrations of $\left(\mathrm{V}^{\mathrm{IV}} \mathrm{O}\right)_{\mathrm{m}} \mathrm{HSA}(0.67 \mathrm{mM}$ in $\mathrm{HSA})$ with additions of maltol. HSA (fatted) was used. The mol ratios of HSA: $\mathrm{V}^{\mathrm{IV}} \mathrm{O}^{2+}$ : maltol are indicated. Measurements were carried out in HEPES-S buffer $(\mathrm{pH}=7.4)$ with an optical path of $5 \mathrm{~cm}$.

According to Orvig [1], when $\mathrm{V}^{\mathrm{IV}} \mathrm{O}^{2+}$ is added to albumin as ions, the first mol equivalent binds VBS1 and further added moles of $\mathrm{V}^{\mathrm{IV}} \mathrm{O}^{2+}$ bind the VBS2-type sites. This is in line with Sanna's report of the formation of multinuclear species when the $\mathrm{V}^{\mathrm{IV}} \mathrm{O}^{2+}$ /albumin ratio is $>1$ [36]. Depending on the amount of $\mathrm{V}^{\mathrm{IV}} \mathrm{O}^{2+}$ added to HSA, there may be several $\left(\mathrm{V}^{\mathrm{IV}} \mathrm{O}\right)_{\mathrm{m}} \mathrm{HSA}$ $(m>1)$ species available to interact with maltol, and at higher ratios of $\mathrm{V}^{\mathrm{IV}} \mathrm{O}$ :HSA there will be a higher number of $\mathrm{V}^{\mathrm{IV}} \mathrm{O}$ centres available to interact with maltol, thus producing more intense $\mathrm{CD}$ spectra in the visible region. The system containing e.g. 1:3.5:10.5 (HSA: $\mathrm{V}^{\mathrm{IV}} \mathrm{O}$ :maltol) will therefore have more intense $\mathrm{CD}$ signals in the visible region than its equivalent containing 1:1.8:5.3 (HSA: $\mathrm{V}^{\mathrm{IV}} \mathrm{O}^{2+}$ : maltol). However, for each type of chiral $\mathrm{V}^{\mathrm{IV}} \mathrm{O}$-species formed, the increase in its concen- 


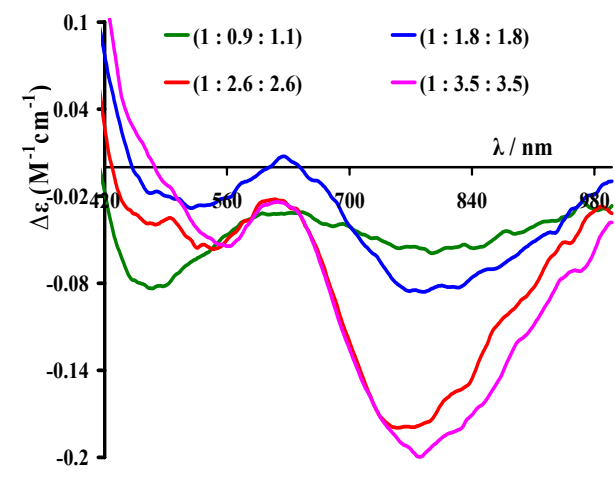

a

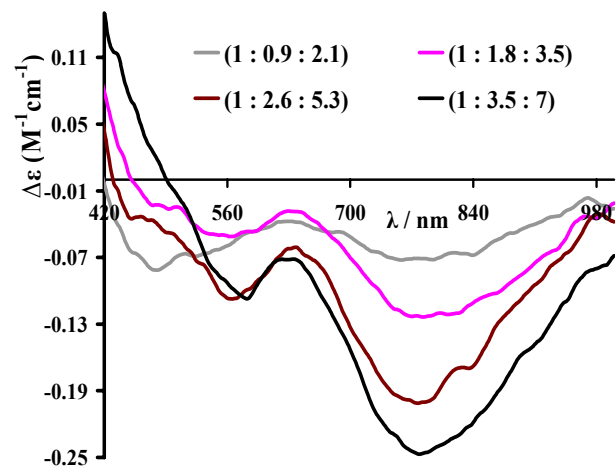

b

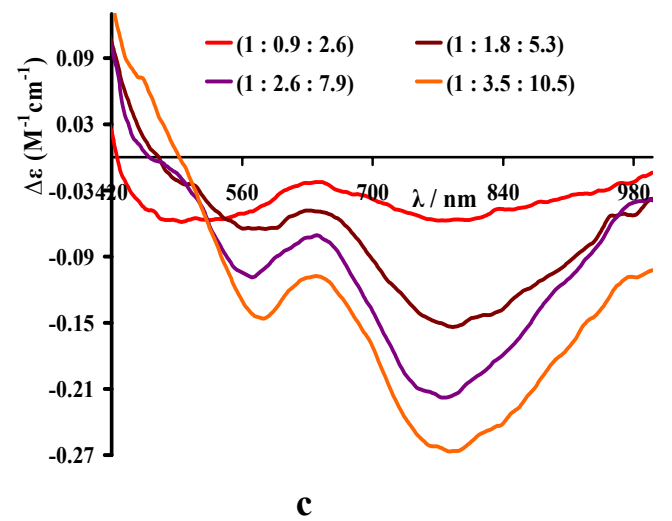

Fig. 12. $\mathrm{CD}$ spectra of titrations of $\left(\mathrm{V}^{\mathrm{IV}} \mathrm{O}\right)_{\mathrm{m}} \mathrm{HSA}$ systems $(0.70 \mathrm{mM}$ in $\mathrm{HSA})$ with maltol. HSA (fatted) was used. The mol ratios of HSA: $\mathrm{V}^{\mathrm{IV}} \mathrm{O}$ : maltol are indicated. As in Figs. $11 \mathrm{~b}, \mathrm{c}$ and $\mathrm{d}$ the mole ratio of maltol to $\mathrm{V}^{\mathrm{IV}} \mathrm{O}^{2+}$ is $\approx 1$ (a), $\approx 2$ in (b) and $\approx 3$ in (c). The CD spectra shown mostly do not cross for $\lambda>550 \mathrm{~nm}$. Measurements were carried out in HEPES-S buffer $(\mathrm{pH}=7.4)$ with an optical path of $5 \mathrm{~cm}$.

tration will imply a proportional increase in the recorded $|\Delta \varepsilon|$ values, but not in the pattern of the spectra. Thus, if changes are observed in the relative intensities of the $\mathrm{CD}$ bands, this means that distinct chiral $\mathrm{V}^{\mathrm{IV}} \mathrm{O}$-complexes are being formed [50-57].

Observation of the patterns of the CD bands in Figures 11 and 12 , namely the relative intensity of the bands at 530-590 $\mathrm{nm}$ and 750-800 nm, show the formation of at least two types of chiral species: (1) when the ratio of maltol: $\mathrm{V}^{\mathrm{IV}} \mathrm{O}^{2+}<1$, and (2) when it is $>1$. In Figure $11 \mathrm{~b}$ an isodichroic point is observed at $\lambda \approx 507 \mathrm{~nm}, \Delta \varepsilon \approx-0.025 \mathrm{M}^{-1} \mathrm{~cm}^{-1}$ suggesting the existence of two distinct types of chiral species in equilibrium when the maltol: $\mathrm{V}^{\mathrm{IV}} \mathrm{O}^{2+}$ ratio is $<1$. When the maltol $/ \mathrm{V}^{\mathrm{IV}} \mathrm{O}^{2+}$ ratio was increased further, e.g. Figure $11 \mathrm{c}$ and $11 \mathrm{~d}$, the type of CD spectra recorded continue to change suggesting the formation of a $3^{\text {rd }}$ distinct type of chiral species. Figure 12 also illustrates the formation of these three distinct types of chiral $\mathrm{V}^{\mathrm{IV}} \mathrm{O}$-species.

Thus important information may be obtained from Figures 11 and 12: (1) When maltol is added to $\left(\mathrm{V}^{\mathrm{IV}} \mathrm{O}\right)_{\mathrm{m}} \mathrm{HSA}$ complex new $\mathrm{V}^{\mathrm{IV}} \mathrm{O}-\mathrm{HSA}$ species form; (2) Distinct species form when the maltol: $\mathrm{V}^{\mathrm{IV}} \mathrm{O}^{2+}$ ratio is $<1$ and when maltol: $\mathrm{V}^{\mathrm{IV}} \mathrm{O}^{2+}$ ratio is $\geq 1$; (3) Increasing concentration of maltol increased the intensity of the negative bands up to $\sim 11$ (band at $\sim 570 \mathrm{~nm}$ ) or $\sim 14$ mol equivalents (band at $\sim 780 \mathrm{~nm}$ ) of maltol; (4) The observed changes in the $\left(\mathrm{V}^{\mathrm{IV}} \mathrm{O}\right)_{\mathrm{m}} \mathrm{HSA}$ spectra upon addition of maltol suggests that maltol interacts with the $\mathrm{V}^{\mathrm{IV}} \mathrm{O}$-centers bound to HSA, and beside the initial $\left(\mathrm{V}^{\mathrm{IV}} \mathrm{O}\right)_{\mathrm{m}} \mathrm{HSA}$ species, com- plexes (maltol) $)_{\mathrm{m}}\left(\mathrm{V}^{\mathrm{IV}} \mathrm{O}\right)_{\mathrm{m}} \mathrm{HSA}$ or (maltol $)_{2 \mathrm{~m}}\left(\mathrm{~V}^{\mathrm{IV}} \mathrm{O}\right)_{\mathrm{m}} \mathrm{HSA}$ may form.

As demonstrated previously [37,38] and emphasized here, the $\mathrm{CD}$ and EPR spectra are compatible with the formation of at least two sets of species (possibly three) when HSA is titrated with $\mathrm{V}^{\mathrm{IV}} \mathrm{O}^{2+}$. Moreover, the oligomeric forms of $\mathrm{V}^{\mathrm{IV}} \mathrm{O}$ formed at VBS1, and possibly also at other sites are not easily observable in the X-band EPR spectrum at $\mathrm{pH}$ 7.4, hence its weak intensity, Figure 13. Upon addition of maltol, this binds to the $\mathrm{V}^{\mathrm{IV}} \mathrm{O}$ centers, the intensity of the EPR signals increase significantly up to $1: 2\left(\mathrm{~V}^{\mathrm{IV}} \mathrm{O}\right.$ :maltol) molar ratio, but not much more after further additions of maltol. Moreover, the field positions do not change suggesting that the $\mathrm{V}^{\mathrm{IV}} \mathrm{O}$-maltol-HSA species formed correspond to identical binding sets, which is certainly not the case, because the type of CD spectra recorded changes.

As shown by the CD spectra, distinct species form when $0,2.8,8.3,13.8$ and 16.5 mol equivalents of maltol were added to e.g. $0.65 \mathrm{mM}\left(\mathrm{V}^{\mathrm{IV}} \mathrm{O}\right)_{3.4} \mathrm{HSA}$. However, Fig. 13 shows the presence of apparently only 'one species' for each spectrum. In fact, the corresponding EPR parameters of the species formed upon each addition of maltol (Table 2) do not show significant changes.

The EPR parameters reported by the group of Orvig for BMOV at $\mathrm{pH} 7.4$ were $A_{\mathrm{z}}=171 \times 10^{-4} \mathrm{~cm}^{-1}$ and $\mathrm{g}_{\mathrm{z}}=1.938$ [1]. Our measured values for BMOV are $A_{\mathrm{z}}=168.8 \times 10^{-4} \mathrm{~cm}^{-1}$ 


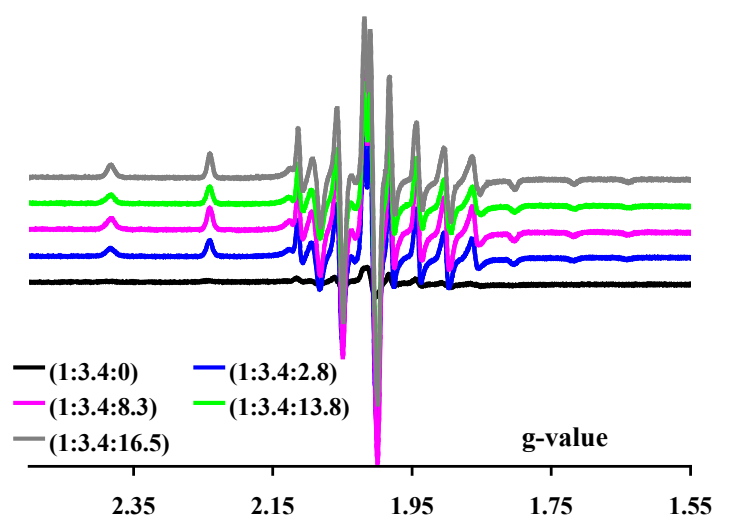

Fig. 13. (a) First derivative X-band EPR spectra of frozen solutions $(77 \mathrm{~K})$ of $\left(\mathrm{V}^{\mathrm{IV}} \mathrm{O}\right)_{3.4} \mathrm{HSA}(0.65 \mathrm{mM}$ in HSA, in HEPES-S buffer, $\mathrm{pH}$ 7.4) and upon additions of maltol. The molar ratios of HSA: $\mathrm{V}^{\mathrm{IV}} \mathrm{O}^{2+}$ : maltol are indicated. The intensity of the spectra is approximately the same for the pink, green and grey spectra.

Table 2. Spin Hamiltonian parameters obtained from the EPR spectra [58] of solutions containing $\left(\mathrm{V}^{\mathrm{IV}} \mathrm{O}\right)_{3.4} \mathrm{HSA}(0.65 \mathrm{mM}$ in fHSA in HEPES-S buffer at $\mathrm{pH} 7.4)$ upon successive additions of maltol.

\begin{tabular}{ccc}
\hline (HSA:V ${ }^{\mathrm{IV}}$ O:maltol) & $g_{\mathrm{z}}$ & $A_{\mathrm{z}} \times 10^{4} \mathrm{~cm}^{-1}$ \\
\hline $1: 3.4: 0$ & 1.946 & 166.5 \\
$1: 3.4: 2.8$ & 1.944 & 166.0 \\
$1: 3.4: 8.3$ & 1.943 & 166.1 \\
$1: 3.4: 13.8$ & 1.943 & 166.6 \\
$1: 3.4: 16.5$ & 1.943 & 166.2 \\
\hline
\end{tabular}

and $g_{z}=1.940$. Comparing the EPR parameters in Table 2 we may state that in the solutions studied the amount of BMOV formed, in any, is small. Thus, the possible stoichiometry of the species that may form are (maltol $)_{\mathrm{m}}\left(\mathrm{V}^{\mathrm{IV}} \mathrm{O}\right)_{\mathrm{m}} \mathrm{HSA}$ and (maltol $)_{2 \mathrm{~m}}\left(\mathrm{~V}^{\mathrm{IV}} \mathrm{O}\right)_{\mathrm{m}} \mathrm{HSA}$.

Orvig \& coworkers [1] also reported the formation of (maltol $)_{\mathrm{m}}\left(\mathrm{V}^{\mathrm{IV}} \mathrm{O}\right)_{\mathrm{m}} \mathrm{HSA}$ ternary species when $\mathrm{V}^{\mathrm{IV}} \mathrm{O}-\mathrm{HSA}$ is titrated with maltol and they objected to the formation of BMOV and (maltol $)_{2 \mathrm{~m}}\left(\mathrm{~V}^{\mathrm{IV}} \mathrm{O}\right)_{\mathrm{m}} \mathrm{HSA}$. Kiss et al. [16] also indicated the formation of ternary albumin (maltol) $)_{\mathrm{m}}\left(\mathrm{V}^{\mathrm{IV}} \mathrm{O}\right)_{\mathrm{m}} \mathrm{HSA}$ from their NMR relaxation dispersion measurements. Garribba [36, $38,59]$ based mostly on EPR data indicated the formation of (maltol $)_{2 \mathrm{~m}}\left(\mathrm{~V}^{\mathrm{IV}} \mathrm{O}\right)_{\mathrm{m}} \mathrm{HSA}$, where the $\mathrm{V}^{\mathrm{IV}} \mathrm{O}$ centers are bound to $\mathrm{N}$-imidazole atoms of His residues. Our results indicate that both (maltol) $)_{\mathrm{m}}\left(\mathrm{V}^{\mathrm{IV}} \mathrm{O}\right)_{\mathrm{m}} \mathrm{HSA}$ and (maltol $)_{2 \mathrm{~m}}\left(\mathrm{~V}^{\mathrm{IV}} \mathrm{O}\right)_{\mathrm{m}} \mathrm{HSA}$ may exist in equilibrium, although species with a $\mathrm{V}^{\mathrm{IV}} \mathrm{O}$ :maltol stoichiometry of 1:2 predominate (if enough maltol is present). The existence of both types of species: $1: 1$ and $1: 2\left(\mathrm{~V}^{\mathrm{IV}} \mathrm{O}^{2+}\right.$ :maltol ratio) bound to HSA is indicated by the change of pattern of the CD spectra as maltol is added to the solutions containing $\mathrm{V}^{\mathrm{IV}} \mathrm{O}^{2+}$ and HSA.

When the $A_{\mathrm{z}}$ values of (maltol $)_{\mathrm{m}}\left(\mathrm{V}^{\mathrm{IV}} \mathrm{O}\right)_{\mathrm{m}} \mathrm{HSA}$ and (maltol $)_{2 \mathrm{~m}}\left(\mathrm{~V}^{\mathrm{IV}} \mathrm{O}\right)_{\mathrm{m}} \mathrm{HSA}$ species are estimated from the possible available donor groups using the additivity rule $[2,60]$, both types of binding sets are compatible with the experimental EPR data obtained considering (1) the variety of coordinating atoms available, namely $\mathrm{N}$-imidazole, $\mathrm{N}$-amine, $\mathrm{O}$-amide and $\mathrm{O}$-carboxylate, and (2) the possibility of forming distorted geometries. Indeed several types of binding sets may yield the same $A_{\mathrm{z}}$ values. In conclusion, based on the previous publications and our present data we propose that in the (maltol $)_{2 \mathrm{~m}}\left(\mathrm{~V}^{\mathrm{IV}} \mathrm{O}\right)_{\mathrm{m}} \mathrm{HSA}$ species the protein bounds to vanadium through the N-imidazole His side chains.

\section{Conclusions}

Reviewing the study of the interaction of $\mathrm{V}^{\mathrm{IV}} \mathrm{O}$ with HSA, including the use of EPR and CD spectra, as well as metal competition studies with $\mathrm{Cu}^{\mathrm{II}}$ and $\mathrm{Zn}^{\mathrm{II}}$ as metal probes, the results confirmed that at least two types of binding sites are present in HSA, more probably three distinct types of sites, which compete not only with each other, but also with hydrolysis of the metal ion. The systems are quite complex and the studies are particularly difficult with fatted albumins where conformational changes, induced by the binding of fatty acids, decrease the ability of $\mathrm{V}^{\mathrm{IV}} \mathrm{O}$ to bind albumin, lowering the intensity of the CD and EPR spectra measured [37].

In one of the sites the resulting $\mathrm{V}^{\mathrm{IV}} \mathrm{O}-\mathrm{HSA}$ complex has a weak visible CD signal and its X-band EPR spectrum may be measured. This was assigned to amino acid side chains of the ATCUN site, but with a distinct binding set from that of $\mathrm{Cu}^{2+}$ [37]. The other binding site shows stronger signals in the CD in the visible range and was assigned to the multi metal binding site (MBS) of HSA. The CD and EPR data recorded with the PSA $+\mathrm{V}^{\mathrm{IV}} \mathrm{O}^{2+}$ system (PSA does not contain the ATCUN site) in the presence of an excess of $\mathrm{Zn}^{\mathrm{II}}$ indicates that a $3^{\text {rd }}$ type of site is present in PSA but probably also in HSA and BSA.

The EPR and CD studies carried out with the HSA-V ${ }^{\mathrm{IV}} \mathrm{O}-$ maltol system indicate that at least two types of chiral $\mathrm{V}^{\mathrm{IV}} \mathrm{O}$ maltol complexes form with 1:1 and 1:2 $\mathrm{V}^{\mathrm{IV}} \mathrm{O}$ :maltol stoichiometry, the (maltol $)_{2 \mathrm{~m}}\left(\mathrm{~V}^{\mathrm{IV}} \mathrm{O}\right)_{\mathrm{m}} \mathrm{HSA}$ type species predominating if enough maltol is present in the solutions.

Not considering the probable binding to transferrin, if both $\mathrm{V}^{\mathrm{IV}} \mathrm{O}^{2+}$ and maltol are present in circulating blood and if equilibrium conditions are achieved, $\mathrm{V}^{\mathrm{IV}} \mathrm{O}^{2+}$ cations may be transported as $\mathrm{HSA}-\mathrm{V}^{\mathrm{IV}} \mathrm{O}$-maltol species.

\section{Acknowledgments}

The work was supported by FEDER, Fundação para a Ciência e Tecnologia, the Ciencia 2007 programme, the Portuguese NMR Network (IST-UTL Center) and PEst-OE/QUI/UI0100/2011, SFRH/BPD/68789/2010, the European Commission for the Erasmus Mundus Master studentship within EMQAL 2008-095, the Hungarian National Research Fund (OTKA K77833), the Hungarian-Portuguese Bilateral Research Fund (TéT 09/2008). TJ thanks for the János Bolyai Research Scholarship of the Hungarian Academy of Sciences. 


\section{References}

1. Liboiron, B. D.; Thompson, K. H.; Hanson, G. R.; Lam, E.; Aebischer, N.; Orvig, C. J. Am. Chem. Soc. 2005, 127, 5104-5115.

2. Rehder, D. Bioinorganic Vanadium Chemistry; John Wiley \& Sons, Ltd: England, 2008.

3. Evangelou, A. M. Crit. Rev. Oncol. Hematol. 2002, 42, 249-265.

4. Papaioannou, A.; Manos, M.; Karkabounas, S.; Liasko, R.; Evangelou, A. M.; Correia, I.; Kalfakakou, V.; Costa Pessoa, J.; Kabanos, T. J. Inorg. Biochem. 2004, 98, 959-968.

5. Noblía, P.; Vieites, M.; Parajón-Costa, B. S.; Baran, E. J.; Cerecetto, H.; Draper, P.; González, M.; Piro, O. E.; Castellano, E. E.; Azqueta, A.; López de Ceráin, A.; Monge-Vega, A.; Gambino, D. J. Inorg. Biochem. 2005, 99, 443-451.

6. Benítez, J.; Guggeri, L.; Tomaz, I.; Costa Pessoa, J.; Moreno, V.; Lorenzo, J.; Avilés, F. X.; Garat, B.; Gambino, D. J. Inorg. Biochem. 2009, 103, 1386-1394.

7. Maurya, M. R.; Khan, A. A.; Azam, A.; Kumar, A.; Ranjan, S.; Mondal, N.; Costa Pessoa, J. Eur. J. Inorg. Chem. 2009, 53775390.

8. Shigeta, S.; Mori, S.; Yamase, T.; Yamamoto, N.; Yamamoto, N. Biomed. Pharmacother. 2006, 60, 211-219.

9. Maiti, A.; Ghosh, S. J. Inorg. Biochem. 1989, 36, 131-139.

10. Ghosh, P.; D’Cruz, O. J.; DuMez, D. D.; Peitersen, J.; Uckun, F. M. J. Inorg. Biochem. 1999, 75, 135-143.

11. Costa Pessoa, J..; Tomaz, I. Curr. Med. Chem. 2010, 17, 37013738.

12. Thompson, K. H.; Lichter, J.; LeBel, C.; Scaife, M. C.; McNeill, J. H.; Orvig, C. J. Inorg. Biochem. 2009, 103, 554-558.

13. Thompson, K. H.; McNeill, J. H.; Orvig, C. Chem. Rev. 1999, 99 , 2561-2571.

14. Sakurai, H.; Kojima, Y.; Yoshikawa, Y.; Kawabe, K.; Yasui, H. Coord. Chem. Rev. 2002, 226 187-198.

15. Thompson, K. H.; Orvig, C. J. Chem. Soc., Dalton Trans. 2000, 2885-2892.

16. Kiss, T.; Jakusch, T.; Hollender, D.; Dörnyei, Á.; Enyedy, É. A.; Costa Pessoa, J.; Sakurai, H.; Sanz-Medel, A. Coord. Chem. Rev. 2008, 252, 1153-1162.

17. Passadouro, M.; Metelo, A. M.; Melão, A. S.; Pedro, J. R.; Faneca, H.; Carvalho, E.; Castro, M. M. C. A. J. Inorg. Biochem. 2010, 104, 987-992.

18. Metelo, A. M.; Pérez-Carro, R.; Castro, M. M. C. A.; López-Larrubia, P. J. Inorg. Biochem. 2012, 115, 44-49.

19. Willsky, G. R.; Chi, L. H.; Godzala, M.; Kostyniak, P. J.; Smee, J. J.; Trujillo, A. M.; Alfano, J. A.; Ding, W. J.; Hu, Z. H.; Crans, D. C. Coord. Chem. Rev. 2011, 255, 2258-2269.

20. Jakusch, T.; Costa Pessoa, J.; Kiss, T. Coord. Chem. Rev. 2011, 255, 2218-2226.

21. Nielsen, F. H. Metal Ions Biol. Syst. 1995, 31, 543-573.

22. Jakusch, T.; Hollender, D.; Enyedy, É. A.; González, C. S.; Montes-Bayón, M.; Sanz-Medel, A.; Costa Pessoa, J.; Tomaz, I.; Kiss, T. Dalton. Trans. 2009, 2428-2437.

23. Thompson, K. H.; Orvig, C. Coord. Chem. Rev. 2001, 1033, 219221.

24. Heinemann, G.; Fichtl, B.; Vogt, W. Br. J. Clin. Pharmacol. 2003, $55,241-245$.

25. Yasui, H.; Takechi, K.; Sakurai, H. J. Inorg. Biochem. 2000, 78, 185-196.

26. Setyawati, I. A.; Thompson, K. H.; Yuen, V. G.; Sun, Y.; Battell, M.; Lyster, D. M.; C.Vo; Ruth, T. J.; Zeisler, S.; McNeill, J. H.; Orvig, C. J. Appl. Physiol. 1998, 84, 569-575.

27. Peters Jr, T. All about albumin: Biochemistry, Genetics, and Medical Applications; Academic Press: San Diego, California, 1996.

28. Murray, R. K.; Granner, D. K.; Mayes, P. A.; Rodwell, V. W. Harper's Illustrated Biochemistry; 26th ed.; McGraw-Hill USA, 2003.
29. Steinhardt, J.; Krijn, J.; Leidy, J. G. Biochem. 1971, 10, 40054015.

30. Blindauer, C. A.; Lu, J.; Stewart, A. J.; Sadler P. J.; Pinheiro, T. J. T. Biochem. Soc. T. 2008, 36, 1317-1321.

31. Bal, W.; Christodoulou, J.; Sadler P. J.; Tucker, A. J. Inorg. Biochem. 1998, 70, 33-39.

32. Sadler, P. J.; Stewart, A. J.; Blindauer, C. A.; Berezenko, S.; Sleep, D. P Natl. Acad. Sci. USA 2003, 100, 3701-3706.

33. Christodoulou, J.; Sadler, P. J.; Tucker, A. Eur. J. Biochem. 1994, 225, 363-368.

34. Yasui, H.; Kunori, Y.; Sakurai, H. Chem. Lett. 2003, 32, 10321033.

35. Kiss, T.; Jakusch, T.; Costa Pessoa J.; Tomaz, I. Coordin Chem Rev 2003, 237, 123-133.

36. Sanna, D.; Garribba, E.; Micera, G. J. Inorg. Biochem. 2009, 103, 648-655.

37. Correia, I.; Jakusch, T.; Cobbinna, E.; Mehtab, S.; Tomaz, I.; Nagy, N. V.; Rockenbauer, A.; Costa Pessoa, J.; Kiss, T. Dalton Trans. 2012, 41, 6477-6487.

38. Sanna, D.; Bíró, L.; Buglyó, P.; Micera, G.; Garribba, E. J. Inorg. Biochem. 2012, 115, 87-99.

39. Chasteen, N. D.; Francavilla, J. J. Phys. Chem. 1976, 80, 867871 .

40. Costa Pessoa, J.; Luz, S. M.; Gillard, R. D. J. Chem. Soc. Dalton Trans. 1997, 569-576.

41. Costa Pessoa, J.; Gagja, T.; Gillard, R. D.; Kiss, T.; Luz, S. M.; Moura, J. J. G.; Tomaz, I.; Telo, J. P.; Torok, I. J. Chem. Soc. Dalton Trans. 1998, 3587-3600.

42. Kiss, T.; Petrohán, K.; Buglyó, P.; Sanna, D.; Micera, G.; Costa Pessoa, J.; Madeira, C. Inorg. Chem. 1998, 37, 6389-6391.

43. Costa Pessoa, J.; Cavaco, I.; Correia, I.; Costa, D.; Henriques, R. T.; Gillard, R. D. Inorg. Chim. Acta 2000, 305, 7-13.

44. Costa Pessoa, J.; Tomaz, I.; Kiss, T.; Buglyó, P. J. Inorg. Biochem. 2001, 84, 259-270.

45. Costa Pessoa, J.; Tomaz, I.; Kiss, T.; Kiss, Buglyó, P. J. Biol. Inorg. Chem. 2002, 7, 225-240.

46. Hirayama, K.; Akashi, S.; Furuya, M.; Fukuhara, K. Biochem. Bioph. Res. Co. 1990, 173, 639-646.

47. Vellenga, L.; Wensing, T.; Egberts, H. J. A.; Dijk, J. E. V. Vet. Res. Commun. 1989, 13, 467-474.

48. Yuan, B.; Murayama, K.; Yan, H. Appl. Spectrosc. 2007, 61, 921927.

49. Sanz-Medel, A.; Jakusch, T.; Hollender, D.; Enyedy, E. A.; Gonzalez, C. S.; Montes-Bayon, M.; Costa Pessoa, J.; Tomaz, I.; Kiss, T. Dalton Trans. 2009, 2428-2437.

50. Costa Pessoa, J.; Vilas Boas, L. F.; Gillard, R. D.; Lancashire, R. Polyhedron 1988, 7, 1245-1262.

51. Costa Pessoa, J.; Correia, I.; Gonçalves, G.; Tomaz, I. J. Arg. Chem. Soc. 2009, 97, 151-165.

52. Costa Pessoa, J.; Vilas Boas, Gillard, L. F. R. D. Polyhedron 1989, 7, 1173-1199.

53. Costa Pessoa, J.; Marques, R. L.; Vilas Boas, L. F.; Gillard, R. D. Polyhedron 1990, 9, 81-99.

54. Costa Pessoa, J.; Vilas Boas, L. F.; Gillard, R. D. Polyhedron 1990, 9, 2101-2125.

55. Costa Pessoa, J.; Antunes, J. L.; Vilas Boas, L. F.; Gillard, R. D. Polyhedron 1992, 11, 1449-1461.

56. Costa Pessoa, J.; Luz, S. M.; Cavaco, I.; Gillard, R. D. Polyhedron 1994, 13, 3177-3198.

57. Costa Pessoa, J.; Luz, S. M., Gillard, R. D. Polyhedron 1995, 14, $1495-1515$.

58. Rockenbauer, A.; Korecz, L. Appl. Magn. Res. 1996, 10, 29-43.

59. Garribba, E.; Sanna, D.; Micera, G. Inorg. Chem. 2010, 49, 174187.

60. Chasteen, N.D.; in Biological Magnetic Resonance (Ed.: J. Reuben), Plenum, New York, 1981, p. 53-119. 


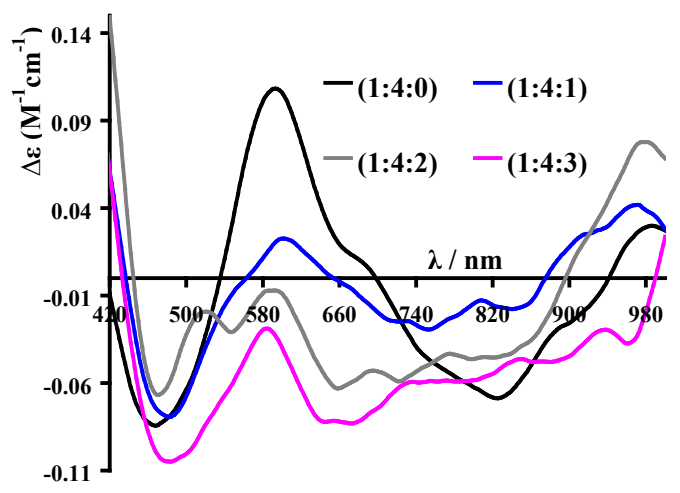

Fig. SI-1 (old Fig. 4). CD spectra of titration of solutions containing $0.5 \mathrm{mM}$ dBSA, $\mathrm{V}^{\mathrm{IV}} \mathrm{OSO}_{4}$ and $\mathrm{ZnCl}_{2}$ solution. The defatted BSA was first loaded with $\sim 4$ mol equivalents of $\mathrm{V}^{\mathrm{IV}} \mathrm{O}^{2+}$. The mol equivalents of added $\mathrm{ZnCl}_{2}$ are: 1, 2, and 3. Measurements were carried out in HEPES-S buffer $(\mathrm{pH}=7.4)$, with an optical path of $5 \mathrm{~cm}$.

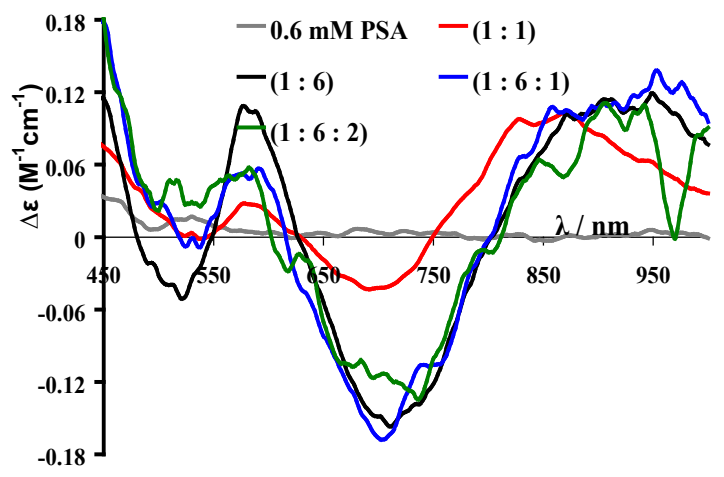

Fig. SI-2 (old 8). CD spectra of a $0.63 \mathrm{mM}$ solution of fPSA (fatted) in HEPES-S buffer $(\mathrm{pH}=7.4)$ and upon additions of 6 mol equivalents of $\mathrm{V}^{\mathrm{IV}} \mathrm{O}^{2+}$, followed by additions of a $56 \mathrm{mM} \mathrm{ZnCl}_{2}$ solution. The mol equivalents of $\mathrm{ZnCl}_{2}$ added were 1 and 2 . The measurements were carried out with an optical path of $5 \mathrm{~cm}$.

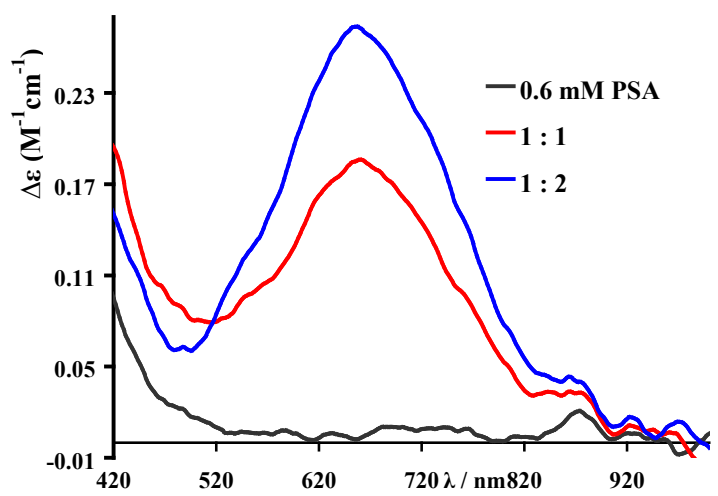

Fig. SI-3 (old 10). CD spectrum of a solution of $0.60 \mathrm{mM}$ fPSA and after additions of 1 and 2 mole equiv of a $\mathrm{Cu}^{\mathrm{II}}$ solution.

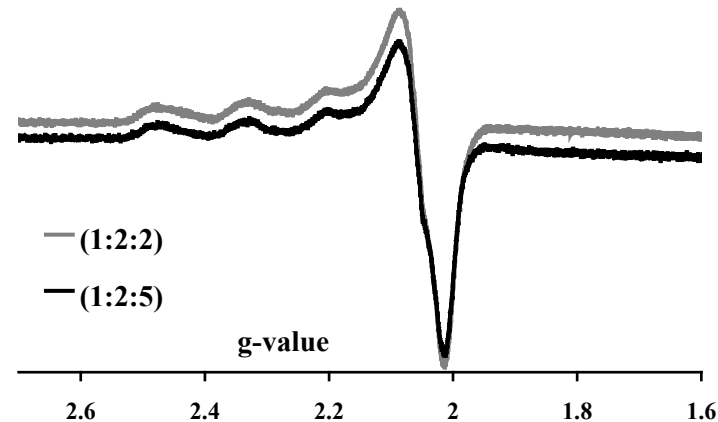

Fig. SI-4 (old 14). The X-band EPR frozen solution spectra (at 77 $\mathrm{K})$ of $\mathrm{Cu}_{2}$ PSA recorded in the presence of $2(1: 2: 2)$ and 5 (1:2:5) mol equivalents of $\mathrm{V}^{\mathrm{IV}} \mathrm{O}\left(\mathrm{ClO}_{4}\right)_{2}$. The $A_{\mathrm{z}}$ values were obtained by simulation of spectra [58]. The solutions were prepared in HEPES-S buffer ( $\mathrm{pH}$ 7.4). 